Katarzyna Żukrowska

\title{
STAN UMÓW UNII EUROPEJSKIEJ \\ Z OTOCZENIEM MIĘDZYNARODOWYM (PRZYKŁAD WNP, PAŃSTW AFRYKI I AZJI)
}

Stan umów między poszczególnymi rynkami narodowymi czy grupami państw bardziej lub mniej zintegrowanych w danym regionie ze sobą ma znaczenie dla obu partnerów takiego związku, wpływając na intensywność konkurencji, zmiany strukturalne gospodarek, możliwości importowe i eksportowe. Intensywność oddziaływania takich więzi zależy od wielu czynników:

- poziomu rozwoju czy raczej stanu zróżnicowania rozwoju między UE a danym partnerem (lub ich grupą);

- rodzaju zastosowanych rozwiązań instytucjonalnych we wzajemnych relacjach;

- warunków wprowadzonych przez umowy instytucjonalizacji;

- w przypadku grupy państw, z którymi UE zawiera umowę, od rodzaju umowy łączącej gospodarki tych państw między sobą;

- dotychczasowych rozwiązań zastosowanych w instytucjonalizacji wzajemnych relacji;

- głębokości i zakresu zmian wynikających z zastosowania nowej umowy;

- percepcji tych zmian na trzech poziomach: rządów, transnarodowych korporacji (TNK) i innych podmiotów działających na rynkach (MiS), obywateli;

- warunków, w jakich dochodzi do wprowadzenia rozwiązań instytucjonalizacji;

- rodzaju efektów, które wprowadzone zmiany wywołają (sfera, widoczność, akceptacja lub odrzucenie).

Jak widać z przedstawionej listy warunków, różna może być siła oddziaływania rozwiązań instytucjonalnych, różne mogą być zastosowane rozwiązania, wreszcie różna będzie skuteczność tych rozwiązań. Wiele jest kombinacji dopuszczalnych rozwiązań, a te mogą skutkować różnymi efektami.

Przykładowo przygotowania do członkostwa w UE państw Europy Środkowej i Wschodniej (poszerzenie 2004-2007) odbywały się w warunkach wzrostu gospodarczego na świecie. Kryzys lat 2007-2008 oraz kryzys strefy euro zmienił percepcję potrzeby dołączenia do głównego nurtu gospodarki światowej, a co za tym idzie poszerzenia i aktywizacji kanałów wzajemnego oddziaływania w sferze gospodarczej. Oznacza to zmianę priorytetów wzajemnego oddziaływania UE i państw partnerskich. Ta nowa sytuacja wywiera również wpływ na potrzebę zmiany oferty UE 
wobec państw partnerskich oraz sfer oddziaływania. Nie musi to oznaczać całkowitego zastąpienia wcześniej stosowanej filozofii, która sprzyjała wzajemnemu zbliżeniu i jego ocenie, ale może i z pewnością powinno prowadzić do jej przewartościowania. UE wielokrotnie w przeszłości wskazywała, że jest zdolna do wprowadzania rozwiązań zindywidualizowanych dla poszczególnych państw czy ich grup w relacjach z własnym rynkiem wewnętrznym i państwami członkowskimi. Dowodem tego były umowy, które mimo stosowania pewnych cech i zasad przyjętych w polityce handlowej Wspólnoty (gradualizm, asymetria, sekwencja itp.) były przygotowywane tak, aby uwzględnić odrębność interesów danej grupy państw, dojrzałość do integracji i jej społeczną akceptację. Proces wzajemnych relacji między UE a grupą państw może również mieć wpływ na określenie pewnych kierunków reform w samej UE. Najlepszym tego przykładem jest kwestia konsolidacji budżetów, czego źródłem może być reforma chociażby systemów emerytalnych. ${ }^{1}$

Obok problemu równowagi fiskalnej, bardzo różnie obecnie postrzeganego przez ekonomistów, czego dowodem jest wystąpienie pani prezes MFW, Christine Lagarde, ${ }^{2}$ coraz częściej zwraca się uwagę na problem kształtowania popytu globalnego jako czynnika stymulującego wzrost i stabilność gospodarki światowej. ${ }^{3}$ Popyt globalny jest wynikiem skumulowanego popytu zgłaszanego przez gospodarki na poszczególnych kontynentach, czy popytu poszczególnych rynków. Metody jego stymulowania zależą od rodzaju popytu (elastyczności popytu zróżnicowanej w zależności od towarów i dochodów), poziomu rozwoju, otwartości gospodarki, intensywności jej powiązań z otoczeniem międzynarodowym, rozwoju infrastruktury, poziomu ryzyka itp.

Instytucjonalizując swoje stosunki z krajami trzecimi, UE kieruje się kilkoma zasadami. Łatwo je prześledzić w procesie instytucjonalizacji relacji między Wspólnotami Europejskimi a krajami Europy Środkowej i Wschodniej, które poprzedziły członkostwo. Przed podpisaniem umowy z WE kraje EŚiW musiały być członkami GATT (obecnie ten wymóg dotyczy członkostwa we WTO). Członkostwo we WTO jest poprzedzone członkostwem w MFW i Banku Światowym. W przypadku czterech państw (Polski, Czech, Słowacji i Węgier) członkostwo w UE poprzedzone zostało członkostwem w OECD, co ułatwiało proces liberalizacji przepływu kapitału (długo-, średnio- i krótkoterminowego). Relacje UE z krajami trzecimi rozpoczynają się od dialogu politycznego. Prowadzi to do powołania do życia wspólnych komisji i grup roboczych, które przygotowują koncepcję współpracy i pozwalają określić zasady,

${ }_{1}$ Global Financial Stability Report. Restoring Confidence and Progressing Reforms, October 2012, World Economic and Financial Survey, IMF, Washington 2012.

2 C. Jones, Lagarde Calls for Caution on Austerity, „Financial Times” October 12, 2012.

3 Global Economic Prospects. Manufacturing Progress amid Turmoil. Expansion of Global Demand, World Bank, Washington, June 2011, s. 6. 
zakres, warunki partnerstwa. Nie ograniczając się do relacji UE z państwami europejskimi, możemy zauważyć, że UE, prowadząc do przygotowania umów partnerskich, wchodzi w rolę zewnętrznego „mentora” kontrolującego zmiany, jakie dane państwo chce przeprowadzić, ich zakres, etapy i skuteczność. Podobne rozwiązanie miało zastosowanie w przypadku państw Europy Środkowej i Wschodniej, które $\mathrm{w}$ fazie przygotowań do członkostwa posługiwały się dwoma rodzajami umów: układami europejskimi oraz umowami o współpracy i handlu (republiki bałtyckie). Co roku, rozpoczynając ten proceder od Agendy 2000, Komisja Europejska publikowała raporty o stanie zaawansowania przygotowań do członkostwa (Progress Reports). Zawierały one informacje szczegółowe, co zostało zrealizowane w procesie przygotowań do członkostwa, a co wymaga odpowiednich korekt i poprawek. Punktem wyjścia ocen były dość ogólnie sformułowane kryteria członkostwa, znane również jako kryteria kopenhaskie, gdyż zostały sformułowane podczas szczytu w Kopenhadze w 1993 roku. ${ }^{4}$

Kryteria kopenhaskie obejmują:

- stabilność instytucji demokratycznych, gwarantujących demokrację i przestrzeganie prawa, praw człowieka i przestrzeganie praw mniejszości narodowych;

- działanie rynku i gospodarki rynkowej, pozwalające na sprostanie presji konkurencji i sił rynkowych, które są odczuwane na rynku wewnętrznym UE;

- zdolność sprostania obowiązkom członkostwa w UE, co jest tożsame z obowiązkiem uczestnictwa w przyszłych procesach tworzenia unii walutowej, gospodarczej i politycznej.

Wymienione kryteria brzmią dość ogólnie, ale w praktyce były przetransponowane na bardzo konkretne wymogi, których realizacja była weryfikowana w każdym z państw kandydackich do członkostwa w UE w procesie akcesji. Perspektywa członkostwa w UE i jego warunki powodowały, że państwa kandydujące poddawały się procesom dostosowawczym, co obejmowało prawodawstwo, instytucje, zmiany mechanizmów działania gospodarki itp. Oznaczało to przyspieszenie procesu tworzenia stabilnych podwalin dla gospodarki rynkowej w sferze ekonomii i demokracji w sferze polityki. ${ }^{5}$

Procesom konwergencji instytucjonalno-prawnej i gospodarczej towarzyszyło poparcie polityków (przedsiębiorstw oraz społeczeństwa). Częściowo akceptacja ta była spowodowana wysoką dynamiką wzrostu gospodarczego w krajach kandydujących do członkostwa, a także silną „chęcią pokonania luki rozwoju i pokonania

${ }^{4}$ European Council in Copenhagen, June 21-22, 1993, Conclusions of the Presidency, s. 12, SN 180/93, http://www.europarl.europa.eu/summits/copenhagen/co_en.pdf (12.10.2012).

5 Transformacja systemowa w Polsce, red. K. Żukrowska, Oficyna Wydawnicza SGH, Warszawa 2010, s. 789 i n. 
dystansu”. Nie bez znaczenia dla akceptacji zmian związanych z przyszłym członkostwem były środki transferowane do państw kandydackich w formie bezpośrednich inwestycji zagranicznych oraz $z$ funduszu PHARE. ${ }^{6}$

\section{UE-WNP}

W relacjach UE-WNP obserwujemy ewolucję. Trudno jednak kierunek zmian wzajemnych powiązań ocenić tu jednoznacznie, wskazując na cel tego procesu: czy będzie to stowarzyszenie, czy członkostwo, utworzenie strefy wolnego handlu, czy też jeszcze inne rozwiązanie? Obecnie można założyć, że interesy i wizja wzajemnych relacji UE-WNP są dość zróżnicowane w poszczególnych państwach WNP, co utrudnia określenie długofalowej perspektywy wzajemnych relacji. Pierwszy etap instytucjonalizacji wzajemnych stosunków między UE a państwami WNP przebiegał według jednolitego modelu, choć czas zawierania poszczególnych umów był różny. Należy podkreślić, że UE zastosowała tu rozwiązanie, które instytucjonalnie umożliwiało państwom WNP dostęp do swego rynku zarówno dla eksportu, jak i importu.

UE podpisała z krajami WNP umowy typu PCA (Partnership Cooparation Agreement - umowy o partnerstwie i współpracy). Wprowadzały one szereg nowych rozwiązań w kontaktach zewnętrznych UE. Po pierwsze, były to umowy w pewnym, ograniczonym zakresie liberalizujące wymianę handlową. Wcześniej umowy liberalizujące wymianę z UE wymagały wcześniejszych umów, a także musiały być poprzedzone członkostwem w GATT/WTO. Po drugie, umowy PCA zawierały Interim Agreement (układ tymczasowy dotyczący liberalizacji wymiany handlowej, który pozwalał wejść w życie części handlowej umowy bez potrzeby jej ratyfikacji7). Po trzecie, umowy PCA były w swym procesie liberalizacji asymetryczne, co oznacza, że dawały dostęp do rynku UE eksporterom z rynków WNP wcześniej, a dopiero po pewnym czasie, z opóźnieniem wymagały wzajemności w tym zakresie dla swoich eksporterów i ich dostępu do rynków WNP.

\footnotetext{
6 Program PHARE - Poland and Hungary Assistance for Restructuring their Economies. Powstał w 1989 roku. Jego fundatorami początkowo były państwa OECD. Od 1990 roku obejmował pozostałe państwa EŚiW i został w całości przejęty przez UE. Do 2000 roku z funduszu PHARE w sumie korzystało 17 państw europejskich. Największym jego beneficjentem była Polska.

7 Wcześniej Interim Agreement zastosowany był w Układzie europejskim Polski. Nie był natomiast zastosowany w przypadku Czech, Słowacji i Węgier. W Polsce stanowił część strategii „szokowej transformacji", która wymagała szybkiego otwarcia gospodarki.
} 
Tabela 1. Porozumienia o partnerstwie i współpracy podpisane przez UE z krajami WNP

\begin{tabular}{|c|c|c|c|c|c|}
\hline Państwo & Decyzja & $\begin{array}{c}\text { Data wejścia } \\
\text { w życie porozumienia }\end{array}$ & Akt prawny & $\begin{array}{c}\text { Data } \\
\text { wygaśnięcia }\end{array}$ & Dalsze rozwiązania \\
\hline Armenia & $\begin{array}{l}99 / 602 / \mathrm{EC} \\
31.05 .1999 \mathrm{r} .\end{array}$ & $1.07 .1999 \mathrm{r}$. & $\begin{array}{l}\text { OJL239 } \\
\text { z 1.09.1999 r. }\end{array}$ & - & \\
\hline Azerbejdżan & $\begin{array}{l}99 / 614 / \mathrm{EC} \\
31.05 .1999 \mathrm{r} .\end{array}$ & $1.07 .1999 \mathrm{r}$. & $\begin{array}{l}\text { OJL246 } \\
\text { z 17.09.1999 r. }\end{array}$ & - & \\
\hline Białoruś & - & $\begin{array}{l}\text { podpisano } \\
\text { w październiku } 1995 \text { r. }\end{array}$ & & $\begin{array}{l}\text { nie weszło } \\
\text { w życie }\end{array}$ & \\
\hline Gruzja & $\begin{array}{l}99 / 515 / \mathrm{EC} \\
31.05 .1999 \mathrm{r} .\end{array}$ & $1.07 .1999 \mathrm{r}$. & $\begin{array}{l}\text { OJL205 } \\
\text { z 4.08.1999 r. }\end{array}$ & - & ENP, ENPI \\
\hline Kazachstan & $\begin{array}{l}\text { 99/490/EC } \\
12.05 .1999 \mathrm{r} .\end{array}$ & $1.07 .1999 \mathrm{r}$. & $\begin{array}{l}\text { OJL196 } \\
\text { z 28.07.1999 r. }\end{array}$ & - & \\
\hline Kirgistan & $\begin{array}{l}\text { 99/491/EC } \\
12.05 .1999 \mathrm{r} .\end{array}$ & $1.07 .1999 \mathrm{r}$. & $\begin{array}{l}\text { OJL196 } \\
\text { z 28.07.1999 r. }\end{array}$ & - & \\
\hline Mołdawia & $\begin{array}{l}\text { 98/401/EC } \\
28.05 .1998 \mathrm{r} .\end{array}$ & $1.07 .1998 \mathrm{r}$. & $\begin{array}{l}\text { OJL181 } \\
\text { z 24.06.1998 r. }\end{array}$ & - & ENP, ENPI \\
\hline Rosja & $\begin{array}{l}97 / 800 / \mathrm{EC} \\
30.10 .1997 \mathrm{r} .\end{array}$ & $1.12 .1997 \mathrm{r}$. & $\begin{array}{l}\text { OJL327 } \\
\text { z 28.11.1997 r. }\end{array}$ & - & $\begin{array}{l}\text { EU-Russia Partnership } \\
\text { for Modernization. } \\
\text { Work Plan }\end{array}$ \\
\hline Ukraina & $\begin{array}{l}\text { 98/149/EC } \\
26.01 .1998 \mathrm{r} .\end{array}$ & $1.03 .1998 \mathrm{r}$. & $\begin{array}{l}\text { OJL049 } \\
\text { z 19.02.1998 r. }\end{array}$ & - & $\begin{array}{l}\text { negocjacje stowarzy- } \\
\text { szenia ENP, ENPI }\end{array}$ \\
\hline Uzbekistan & $\begin{array}{l}\text { 98/149/EC } \\
26.01 .1999 \text { r. }\end{array}$ & $1.07 .1999 \mathrm{r}$. & $\begin{array}{l}\text { OJL229 } \\
\text { z 31.08.1999 r. }\end{array}$ & - & \\
\hline Tadżykistan & $\begin{array}{l}\text { 2009/989EC } \\
29.01 .2009 \mathrm{r} \text {. }\end{array}$ & $1.01 .2010 \mathrm{r}$. & $\begin{array}{l}\text { OJL350 } \\
\text { z 29.12.2009 r. }\end{array}$ & - & \\
\hline
\end{tabular}

Źródło: Zestawienie własne na podstawie dokumentów UE.

Od daty podpisania wejścia w życie umów PCA z krajami WNP upłynął długi okres. Przykładowo Rosja podpisała umowę PCA z UE jeszcze w 1994 roku. Jednak umowy, a konkretnie ich część handlowa wchodziła w życie przed zakończeniem procedury ratyfikacji i wejściem w życie całości dokumentu i zawartych w nim warunków. W przypadku Rosji nastąpiło to w 1997 roku.

Umowy PCA zostały zawarte przed członkostwem państw EŚiW w UE. Państwa EŚiW nie miały wcześniej umów z Rosją, ani z większością państw WNP. ${ }^{8}$ Umowy PCA (w ramach wspólnej polityki handlowej UE) po uzyskaniu członkostwa przez państwa EŚiW w UE włączyły te państwa do PCA. Rozwiązanie to stanowiło jeden z elementów niezgody i prób protestów ze strony państw WNP, a zwłaszcza Rosji. Nie zostało jednak wzięte pod uwagę i stało się podstawą do wymiany handlowej między nowymi państwami członkowskimi UE a państwami WNP.

${ }^{8}$ M. Dabrowki, Economic relations between the EU and CIS. (An Overview), „Problems of Economic Transition” April 2008, Vol. 50 (112), s. 46-70. 
Umowy PCA zostały zawarte na dziesięć lat. ${ }^{9}$ Po tym okresie mogły zostać przedłużone lub zastąpione nowymi umowami. Pierwszą z umów, która wygasła, była umowa z Rosją. Nie przedłużano jej przez dwa lata w efekcie protestu Polski, która miała zablokowany dostęp dla swego eksportu rolnego na rynek Rosji. Po unormowaniu rozwiązań dotyczących dostępu polskich eksporterów dóbr rolnych i spożywczych umowa PCA UE-Rosja została przedłużona. Podobna sytuacja była z Ukrainą. Członkostwo w WTO wymagało od Ukrainy i Rosji podpisania z UE wielu umów branżowych. Stanowią one podstawę do wymiany handlowej między tymi dwoma rynkami a UE. Lista tych umów jest długa, dotyczą m.in. handlu surówką żelaza, limitów ilościowych, odpadów radioaktywnych, tekstyliów. Listę umów bilateralnych podpisanych przez Rosję ${ }^{10}$ i Ukrainę, ${ }^{11}$ podobnie jak pozostałe państwa WNP, oraz ich treść można znaleźć na stronie zewnętrznych kontaktów UE.

Tabela 2. Główni partnerzy UE w 2011 roku - import

\begin{tabular}{|l|l|c|l|l|c|}
\hline Pozycja w handlu & \multicolumn{1}{|c|}{ Państwo } & Udziat (w \%) & Pozycja w handlu & \multicolumn{1}{|c|}{ Państwo } & Udział (w \%) \\
\hline 1 & Chiny & 17,3 & 8 & Indie & 2,3 \\
\hline 2 & Rosja & 11,8 & 9 & Brazylia & 2,2 \\
\hline 3 & USA & 10,9 & 10 & Korea Płd. & 2,1 \\
\hline 4 & Norwegia & 5,6 & 16 & Kazachstan & 1,3 \\
\hline 5 & Szwajcaria & 5,4 & 24 & Ukraina & 0,9 \\
\hline 6 & Japonia & 4,0 & 25 & Azerbejdżan & 0,9 \\
\hline 7 & Turcja & 2,8 & 49 & Białoruś & 0,3 \\
\hline
\end{tabular}

Źródło: Eurostat, Main Economic Indicators, EU.

Zestawienie głównych partnerów handlowych UE wskazuje na duże asymetrie w relacjach UE z jej partnerami. Dla partnerów spoza Unii jest ona jednym z ważniejszych rynków importowych i eksportowych, podczas gdy dla UE udział tych partnerów w wymianie handlowej już takiej roli nie odgrywa. Ta asymetria wskazuje na możliwość przyciągania rynku UE dla partnerów i siłę oddziaływania na decyzje dotyczące liberalizacji i instytucjonalizacji. Podobną asymetrię można było zaobserwować w przypadku państw EŚiW, dla których rynek UE stanowił średnio około $60 \%$, podczas gdy one dla UE stanowiły $2-3 \%$ obrotów. Taka asymetria jest wynikiem zróżnicowania rozwoju, a także jego warunków. W przypadku państw UE

9 Wschód jako partner Unii Europejskiej, red. M. Dobroczyński, M. Lipiec-Zajchowska, Wydawnictwo Naukowe Wydziału Zarządzania UW, Warszawa 2005, s. 33-50.

$10 \mathrm{http}: / /$ ec.europa.eu/world/agreements/searchByCountryAndContinent.do? countryId=3853 \&countryName=Russia (12.10.2012).

$11 \mathrm{http} / /$ ec.europa.eu/world/agreements/searchByCountryAndContinent.do? countryId=3856\& countryName=Ukraine $(12.10 .2012)$. 
(czy szerzej OECD) był to rozwój stymulowany przez konkurencję, udział w międzynarodowym podziale pracy czy wspólnych badaniach. Dla państw EŚiW był to rozwój poza głównym nurtem gospodarki światowej, bez konkurencji i uczestnictwa w międzynarodowym podziale pracy. Dysproporcje te można jedynie pokonać przez liberalizowanie kontaktów i współpracę międzynarodową opartą na przepływie czynników produkcji. Występujące tu różnice poziomu rozwoju można w tym składzie uznać za warunek sprzyjający współpracy i przyspieszający zmiany strukturalne. Niemniej ta współpraca musi zakładać instytucjonalne rozwiązania sprzyjające liberalizacji i stymulowaniu zmian. Podobnym rozwiązaniom powinny sprzyjać różnice w poziomie wymiaru podatków, różnice w kosztach jednostkowych pracy, przy dużym i komplementarnym potencjale intelektualnym.

Tabela 3. Partnerzy UE w 2011 roku - eksport

\begin{tabular}{|l|l|c|l|l|c|}
\hline Pozycja w handlu & Państwo & Udziat $(\mathrm{w} \%)$ & Pozycja w handlu & \multicolumn{1}{|c|}{ Państwo } & Udział (w \%) \\
\hline 1 & USA & 17,0 & 8 & Indie & 2,6 \\
\hline 2 & Chiny & 8,9 & 9 & Brazylia & 2,3 \\
\hline 3 & Szwajcaria & 7,9 & 10 & Zjednoczone Emiraty & 2,1 \\
\hline 4 & Rosja & 7,1 & 19 & Arabskie & 1,4 \\
\hline 5 & Turcja & 4,7 & 36 & Ukraina & 0,5 \\
\hline 6 & Japonia & 3,2 & 37 & Białoruś & 0,4 \\
\hline 7 & Norwegia & 3,0 & & Kazachstan & \\
\hline
\end{tabular}

Źródło: Eurostat, Main Economic Indicators, EU.

Przyglądając się udziałom wysoko rozwiniętych państw OECD w wymianie UE, możemy wyciągnąć wniosek, że brak między nimi wolnego handlu jest czynnikiem sprzyjającym rozwojowi rynków, które liberalizują z nimi handel. Zwłaszcza w warunkach zróżnicowania rozwojowego oraz liberalizacji przepływu kapitału, technologii i własności intelektualnej. Ma to szczególne znaczenie np. dla Turcji w jej handlu z UE w ramach unii celnej. Co również sprzyja liberalizacji wymiany handlowej Turcji z krajami, które liberalizują na różnych warunkach swoją wymianę z UE. Podobna uwaga może dotyczyć liberalizacji handlu z Meksykiem (członek NAFTA i umowa stowarzyszenia $z$ UE), Koreą Płd. (strefa wolnego handlu z USA i UE), negocjowanie warunków wolnego handlu z Mercosur (USA i UE).

Część państw WNP objętych jest ENP (European Neighborhood Policy) - Europejską Polityką Sąsiedztwa. Państwa WNP objęte polityką ENP nie mają obowiązku deklarowania przyszłego członkostwa w UE. Rosja - choć jest państwem bezpośrednio graniczącym z terytorium UE - nie jest objęta ENP. Może natomiast korzystać z Instrumentu Finansowego Polityki Sąsiedztwa na równi z pozostałymi państwami WNP, które są objęte wschodnim kierunkiem polityki sąsiedztwa. 
Od ustaleń przyjętych podczas szczytu w Petersburgu w 2003 roku UE z Rosją zaczęły tworzyć cztery przestrzenie (wspólne obszary). Proces ten obejmuje sferę gospodarki, sferę wolności, bezpieczeństwa i sprawiedliwości, sferę zewnętrznego bezpieczeństwa oraz sferę badań naukowych, edukacji i kultury. W 2005 roku na dwóch kolejnych szczytach (maj i październik 2005 roku) przyjęto kolejno pakiet map drogowych sprzyjających tworzeniu czterech wspólnych obszarów, co doprowadziło do sformułowania praktycznych zaleceń ich realizacji podczas kolejnego londyńskiego szczytu w 2005 roku. W ramach tworzenia wspólnych przestrzeni z UE Rosja uczestniczy w badaniach finansowanych $\mathrm{z}$ kolejnych ramowych programów UE, może być ich koordynatorem. Wspólnie z ośrodkami z państw UE prowadzi się badania nad technologiami niskosurowcowymi, w tym niskoenergetycznymi. Można uznać za zaawansowane również badania nad czystymi technologiami. Niemniej jednak trudno uznać prowadzone tu działania za w pełni sprzyjające wykorzystaniu istniejących potencjałów, po obu stronach partnerstwa.

W grudniu 2011 roku Rosja zakończyła negocjacje warunków członkostwa we WTO. Wydarzenie to jest jednym z warunków przygotowania nowej umowy z UE. Być może nowa umowa między Rosją a UE będzie stanowiła model dla umów negocjowanych w przyszłości również z pozostałymi państwami WNP.

Tabela 4. Unijny handel z Rosją w latach 2007-2011

\begin{tabular}{|c|c|c|c|c|c|}
\hline Rok & $\begin{array}{c}\text { Import UE } \\
(\text { w mln euro })\end{array}$ & $\begin{array}{c}\text { Udział w imporcie UE } \\
(\mathrm{w} \%)\end{array}$ & $\begin{array}{c}\text { Eksport UE } \\
(\mathrm{w} \text { mln euro })\end{array}$ & $\begin{array}{c}\text { Udział w eksporcie } \\
\text { UE (w \%) }\end{array}$ & $\begin{array}{c}\text { Bilans obrotów UE- } \\
\text {-Rosja (w mln euro) }\end{array}$ \\
\hline 2007 & 144981 & 10,1 & 89082 & 7,2 & -55899 \\
\hline 2008 & 178148 & 11,4 & 65578 & 8,0 & -73313 \\
\hline 2009 & 117689 & 9,7 & 65578 & 6,0 & -52111 \\
\hline 2010 & 160058 & 10,6 & 86131 & 6,4 & -73927 \\
\hline 2011 & 198178 & 11,8 & 108449 & 7,1 & -89729 \\
\hline
\end{tabular}

Źródło: Eurostat, Main Economic Indicators, Russia.

Eksport z UE do Rosji obejmuje przede wszystkie produkty przemysłowe wysoko przetworzone, w tym samochody osobowe i ich części, lekarstwa, sprzęt telekomunikacji (aparaty telefoniczne i części zapasowe do nich), traktory i części zapasowe do nich. ${ }^{12}$ Kraje UE importują z Rosji głównie surowce: ropę, gaz i inne. Towarowa struktura eksportu z Rosji nie prezentuje zmian strukturalnych, które zachodzą w gospodarce tego państwa. Jeszcze w 1991 roku struktura produkcji PKB w Rosji tworzona była przez produkcję rolną $(14,3 \%)$, produkcję przemysłową $(47,6 \%)$

12 K.A. Kłosiński, Rosja - ambicje i możliwości w XXI wieku, Wydawnictwo KUL, Lublin 2010, s. 139-160. 
i produkcję usług $(38,1 \%)$. Już w 2001 roku PKB w dominującej części było wytwarzane przez usługi $(57,7 \%)$, przemysł $(35,7 \%)$ oraz rolnictwo $(6,6 \%)$. Kolejne dziesięciolecie przyniosło kontynuację zmian w kierunku postindustrialnej struktury wytwarzania PKB. W 2010 roku - ostatnim, dla którego dostępne są porównywalne dane w Eurostacie - struktura wytwarzania PKB w Rosji przedstawiała się następująco: usługi (59,3\%), przemysł $(36,7 \%)$ oraz rolnictwo $(4,0 \%) .{ }^{13}$

UE negocjuje z Ukrainą całkowicie nowe porozumienie, stanowiące część porozumienia dotyczącego stowarzyszenia z UE. Ostatnia runda negocjacji odbyła się 19-23 września 2011 roku. UE jest jednym z ważniejszych partnerów Ukrainy, o czym decyduje fakt, że wymiana z rynkiem UE to jedna trzecia handlu Ukrainy. Od 16 maja 2008 roku Ukraina jest członkiem WTO, co stało się dzięki silnemu wsparciu Komisji i poszczególnych państw członkowskich UE (w tym Polski).

Tabela 5. Główni partnerzy Rosji w 2010 roku - import

\begin{tabular}{|l|l|c|c|c|l|c|c|}
\hline Pozycja & Państwo & $\begin{array}{c}\text { Wartość } \\
\text { (w mln euro) }\end{array}$ & Udział (w \%) & Pozycja & Państwo & $\begin{array}{c}\text { Wartość } \\
\text { (w mln euro) }\end{array}$ & $\begin{array}{c}\text { Udział } \\
\text { (w \%) }\end{array}$ \\
\hline 1 & UE & 70438,3 & 43,1 & 9 & Kazachstan & 1958,9 & 1,2 \\
\hline 2 & Chiny & 29577,5 & 18,1 & 10 & Szwajcaria & 1828,3 & 1,1 \\
\hline 3 & Ukraina & 10596,2 & 6,5 & 11 & Indie & 1627,5 & 1,0 \\
\hline 4 & Japonia & 7783,3 & 4,8 & 12 & Uzbekistan & 1152,6 & 0,7 \\
\hline 5 & USA & 7453,8 & 3,4 & 27 & Mołdawia & 315,8 & 0,2 \\
\hline 6 & Korea Płd. & 5521,8 & 3,4 & 28 & Kirgistan & 295,6 & 0,2 \\
\hline 7 & Turcja & 3689,2 & 2,3 & 29 & Azerbejdżan & 291,2 & 0,2 \\
\hline 8 & Brazylia & 3095,3 & 1,9 & 40 & Tadżykistan & 160,8 & 0,1 \\
\hline
\end{tabular}

Źródło: Eurostat, Main Economic Indicators, Russia.

Zestawienie partnerów handlowych Rosji w imporcie i w eksporcie wskazuje, że od momentu rozwiązania byłego ZSRR nastąpiło silne przeorientowanie strumieni handlu z rynku byłych republik na handel z krajami spoza obszaru b. ZSRR. Wyjątek stanowi tu Ukraina, która zajmuje w obrotach Rosji wysoką pozycję zarówno w imporcie, jak i eksporcie Rosji. Kontakty w ramach BRIC z pewnością mają wpływ na wzrost znaczenia obrotów między państwami tej grupy. Zwraca uwagę wysoka pozycja UE - pierwsze miejsce w imporcie i w eksporcie Rosji. Niemniej jednak obserwuje się w tych obrotach ujemny bilans dla UE-27. Oznacza to nadwyżkę w eksporcie z Rosji na rynek UE-27, liczony łącznie i deficyt dla UE jako całości, jeśli policzyć $\mathrm{w}$ formie skumulowanej dla wszystkich państw członkowskich.

13 Eurostat, Main Economic Indicators, Russia. 
Tabela 6. Główni partnerzy Rosji w 2010 roku - eksport

\begin{tabular}{|l|l|c|c|c|l|c|c|}
\hline Pozycja & Państwo & $\begin{array}{c}\text { Wartość } \\
\text { (w mln euro) }\end{array}$ & Udział (w \%) & Pozycja & Państwo & $\begin{array}{c}\text { Wartośćc } \\
\text { (w mln euro) }\end{array}$ & Udział (w \%) \\
\hline 1 & UE & 138560,6 & 49,4 & 9 & Indie & 4057,7 & 1,4 \\
\hline 2 & Chiny & 14918,0 & 5,3 & 10 & Kazachstan & 3853,1 & 1,4 \\
\hline 3 & Turcja & 10549,6 & 3,8 & 11 & Iran & 2531,3 & 0,9 \\
\hline 4 & Ukraina & 10444,8 & 3,4 & 12 & Singapur & 1517,2 & 0,9 \\
\hline 5 & Japonia & 9444,8 & 3,4 & 14 & Brazylia & 1302,7 & 0,5 \\
\hline 6 & USA & 9058,5 & 3,2 & 15 & Uzbekistan & 1257,1 & 0,4 \\
\hline 7 & Korea Płd. & 7885,2 & 2,8 & 18 & Azerbejdżan & 1114,8 & 0,4 \\
\hline 8 & Szwajcaria & 6478,0 & 2,3 & 22 & Kirgistan & 736,7 & 0,3 \\
\hline
\end{tabular}

Źródło: Eurostat, Main Economic Indicators, Russia.

Dysproporcje występujące między eksportem Rosji a importem wskazują, z jednej strony, na surowcowy charakter produkcji tej gospodarki, z drugiej zaś na możliwość kumulowania środków, które pochodzą z nadwyżek w handlu zdominowanego przez eksport ropy i gazu. Uzyskane tu dane można interpretować w różny sposób. Można się zastanawiać, jakiego rodzaju reakcji należy się spodziewać ze strony decydentów w Rosji, jeśli ceny surowców energetycznych zaczną spadać. Czy sytuacja taka wpłynie przychylnie na decyzje dotyczące liberalizacji wymiany handlowej z otoczeniem międzynarodowym, czy też przeciwnie, wpłynie na usztywnienie stanowiska odnośnie protekcji rynku Rosji? Decyzja o liberalizacji byłaby w tym przypadku próbą rekompensaty utraconych wskutek spadku cen dochodów ze sprzedaży. W takiej sytuacji liberalizacja wymiany oznaczałaby możliwość utrzymania dotychczasowych ilości eksportowanych ropy lub nawet ich wzrost. Dochody państwa byłyby dodatkowo rekompensowane przez wolumen uzyskiwanych dochodów z ceł importowych, a także z podatku od wartości dodanej, co stanowiłoby pochodną potanienia importu towarów i sług z zagranicy.

Tabela 7. Unijny handel z Ukrainą w latach 2007-2011

\begin{tabular}{|c|c|c|c|c|c|}
\hline Lata & $\begin{array}{c}\text { Import } \\
(w \text { mln euro })\end{array}$ & $\begin{array}{c}\text { Udział w imporcie UE } \\
(w \%)\end{array}$ & $\begin{array}{c}\text { Eksport } \\
(w \text { mln euro) }\end{array}$ & $\begin{array}{c}\text { Udział w eksporcie } \\
\text { UE }(w \text { \%) }\end{array}$ & $\begin{array}{c}\text { Bilans UE-Ukraina } \\
\text { (w mln euro) }\end{array}$ \\
\hline 2007 & 12419 & 0,9 & 22377 & 1,8 & 9958 \\
\hline 2008 & 14547 & 0,9 & 25092 & 1,9 & 10545 \\
\hline 2009 & 7909 & 0,7 & 13924 & 1,3 & 6015 \\
\hline 2010 & 11466 & 0,8 & 17352 & 1,3 & 6015 \\
\hline 2011 & 14975 & 0,9 & 21157 & 1,4 & 6222 \\
\hline
\end{tabular}

Źródło: Eurostat, Main Economic Indicators, Ukraine.

Największym partnerem dla Ukrainy jest Rosja (w imporcie 36,2\%, w eksporcie $26,2 \%$ ), na drugim miejscu UE-27 (w imporcie 31,3\%, w eksporcie 25,5\%). Te dwie 
pierwsze pozycje dotyczą zarówno importu, jak i eksportu. Dalej kolejne miejsca w imporcie Ukrainy zajmują Chiny (7,7\%), Białoruś $(4,2 \%)$ oraz USA $(2,9 \%)$. W eksporcie po Rosji i UE-27 trzecie miejsce przypada Turcji (5,9\%), czwarte Białorusi $(3,7 \%)$, piąte Indiom $(2,8 \%)$. Ukraina, podobnie jak Rosja, zmieniła swoje rynki importowe i eksportowe.

Interesujące jest zestawienie udziału „blokowych” czy „grupowych” partnerów Ukrainy. Obok UE, która jest pierwszym partnerem Ukrainy, w obrotach tego państwa wyraźnie widać wysoki udział państw BRIC $(45,8 \%)$, CIS $(43,8 \%)$ i NAFTA $(3,3 \%){ }^{14}$ Bardzo wysoki udział BRIC i CIS częściowo jest pochodną wysokiego udziału Rosji w wymianie handlowej Ukrainy.

Rynki wschodzące lub państwa rozwijające się preferują „otwieranie się" na stosunki handlowe (gospodarcze) z gospodarkami reprezentującymi podobny poziom rozwoju. Im wyższy jest udział w wymianie handlowej danego państwa czy grupy, tym więcej jest argumentów za otwarciem gospodarki na wzajemne relacje. Łatwiej - z psychologicznego punktu widzenia - otwierać się na kontakty handlowe (gospodarcze) z gospodarkami reprezentującymi wyższy poziom rozwoju, jeśli dynamika ich wzrostu jest relatywnie niska, jeśli charakteryzują się one wysoką stopą bezrobocia i jeśli przeżywają kryzys. Taką sytuację mamy w krajach OECD (w większości). USA osłabły po kryzysie 2007-2008+, a gospodarka UE jest trawiona kryzysem strefy euro. Dodatkowo Rosja z UE-27 ma dodatni bilans na rachunku bieżącym. Zebranie tych dowodów wskazuje, że państwa Europy Wschodniej (czy szerzej - państwa utworzone po rozpadzie b. ZSRR) mogą zdecydować się na otwarcie swoich rynków w ramach BRIC, WNP i NAFTA. Rosja ma warunki do otwarcia się również na wymianę z UE. Niemniej jednak - jak dotąd - Rosja nie przejawiała zainteresowania umową instytucjonalną, która określałaby długotrwałe relacje między Rosją a UE. Takie zainteresowanie i negocjacje widoczne są w przypadku Ukrainy. Ukraina z kolei nie ma jednak zbyt dużego udziału importu i eksportu w relacjach z UE-27, który mógłby być porównany do udziału np. Rosji i UE w imporcie i eksporcie. Rosja dla Ukrainy jest zarówno pierwszym partnerem eksportowym (26,2\%), jak i importowym (36,2\%). Podczas gdy UE-27 zajmuje wysoką drugą pozycję w imporcie $(31,3 \%)$ i eksporcie Ukrainy $(25,5 \%) \cdot{ }^{15}$ Jeśli Ukraina podpisze umowę liberalizacyjną z UE przed Rosją, a wszystko na to wskazuje, podobnie jak przed Rosją uzyskała członkostwo w WTO, to takie rozwiązanie instytucjonalne w pewnym sensie

14 Eurostat, Main Economic Indicators, Ukraine.

15 Ibidem; Eurostat, Main Economic Indicators, Russia. 
będzie mogło stanowić dla Ukrainy podstawę do powtórzenia strategii transformacji, przez którą przeszła Polska.

Ważnym rozwiązaniem, które powinno towarzyszyć nowej umowie Ukrainy z UE, powinna być liberalizacja przepływu kapitału. Środki zarobione przez Ukraińców okresowo pracujących za granicą prawdopodobnie nie wystarczą do stworzenia odpowiedniej liczby miejsc pracy. Podobnie powinien być oceniany potencjał finansowy własnych inwestorów. Niemniej jednak dotychczasowa droga Ukrainy, podobnie jak Rosji od 1989 roku, stworzyła podstawy do rozwijania średniej klasy, która w przyszłości będzie mogła stanowić oparcie dla stabilnego systemu demokratycznego, co jest warunkiem dokończenia procesu transformacji systemowej. Ekonomia bowiem jest polityczna. Bez poparcia społeczeństwa nie można przeprowadzić wymaganych reform, zwłaszcza że niosą one określone koszty. W przypadku państw WNP możliwość ograniczenia społecznych kosztów transformacji stwarzają rynki wschodzące BRIC. Starając się to skrótowo wyjaśnić, należy powiedzieć, że transformacja w EŚiW oparta była na imporcie z rynków OECD (zwłaszcza UE, EFTA, USA, Kanady, Japonii), co wiązało się z relatywnie wysokimi kosztami tego procesu, jeśli uwzględni się poziom płac w gospodarce poddanej transformacji i poziom cen importowanych towarów. Zdecydowanie niższe koszty społeczne tego procesu może przynieść import towarów konsumpcyjnych, wyprodukowanych według najnowszych technologii w Chinach, Indiach czy Brazylii. ${ }^{16}$

Już obecnie BIZ, o których nie pisano zbyt wiele w analizie, tworzą miejsca pracy w Rosji i na Ukrainie, angażując się w produkcję wysokiej jakości niszowych towarów, które są eksportowane na rynek UE. Dowodem na zaangażowanie państw europejskich $\mathrm{w}$ procesy przemian w państwach WNP jest m.in. fakt, że Polska i Ukraina uzyskały razem możliwość goszczenia Euro 2012, co wymagało przygotowania odpowiedniej infrastruktury. Był to również klasyczny czynnik typu keynesowskiego, nakręcający koniunkturę. To na razie początek tego procesu. Umowy z państwami WNP, które zastąpią umowy PCA, będą prowadzić do zwiększenia udziału rynku UE w wymianie handlowych tych państw.

UE sprzyja procesom instytucjonalizacji między państwami WNP. Procesy te nie są jednak zbyt efektywne i łatwe do śledzenia. Państwa tworzą struktury współpracy, następnie je łączą lub z nich występują. Większość tych struktur jest nieaktywna.

16 Na marginesie można powiedzieć, że po stanie wojennym 1981 roku w Polsce głównym naszym partnerem handlowym stały się Niemcy (RFN). Udział UE w polskim handlu znacznie powiększył się po dołączeniu do UE 3 państw EFTA (Austrii, Finlandii i Szwecji). Przed uzyskaniem członkostwa w UE udział tego rynku w polskiej wymianie handlowej przekraczał 60\%. W sumie w 1989 roku więzi Polski były większe z WE, niż ma to miejsce obecnie w przypadku Rosji i Ukrainy. Wyższe też było poparcie społeczeństwa dla przemian i członkostwa w NATO (80\%) oraz EWG (62\%). 
Wokół Rosji powstała unia celna, która obejmuje: Białoruś, Kazachstan, Kirgistan, Rosję, Tadżykistan i Uzbekistan. Wokół Ukrainy powstał GUAM - strefa wolnego handlu. GUAM obejmuje Azerbejdżan, Gruzję, Mołdawię i Ukrainę. Najskuteczniej działa CSTO (Organizacja Traktatu Zbiorowego Bezpieczeństwa). CSTO obejmuje: Armenię, Kazachstan, Kirgistan, Rosję, Tadżykistan, Uzbekistan i od 1993 roku Gruzję oraz Białoruś. Rosja utworzyła z Białorusią i Kazachstanem w 2010 roku Unię Celną, w 2012 roku planowano przekształcić ją w rynek wewnętrzny. W 2003 roku Rosja planowała utworzenie w ramach WNP Wspólnego Obszaru Gospodarczego. W sumie propozycja spotkała się z poparciem 4 państw WNP: Rosji, Białorusi, Kazachstanu i Ukrainy. Utworzona organizacja posiada wspólną komisję ds. handlu o ponadnarodowych kompetencjach. ${ }^{17}$

\section{UE-państwa Afryki (Północnej, Środkowej, Południowej)}

Unia Europejska jest zaangażowana w procesy przemian w Afryce. W tym zakresie współpracuje (różne instytucje UE) z całym kontynentem afrykańskim, z poszczególnymi państwami oraz grupami państw. W 2005 roku UE przyjęła strategię, która ma być podstawą do stworzenia paktu między Europą a Afryką na rzecz przyspieszenia rozwoju w Afryce. ${ }^{18}$ Współpraca między UE a całym kontynentem afrykańskim jest możliwa po utworzeniu Unii Afrykańskiej na szczycie w Lome (Togo) w 2000 roku. Umowa podpisana przez 53 państwa afrykańskie weszła w życie w 2001 roku. ${ }^{19}$

W strategii Afryka-UE chodzi przede wszystkim o osiąganie celów milenijnych ONZ, choć można założyć, że w przypadku UE ma to szerszy kontekst, obejmujący rozwiązania pokojowe, tworzenie społeczeństwa obywatelskiego, trwałych podstaw demokracji oraz warunków do trwałego rozwoju. Realizacja strategii wsparta jest instrumentem finansowym, oprócz tego w dokumencie umożliwia się zaangażowanie EBI (Europejskiego Banku Inwestycyjnego), co ma stanowić bezpośrednie wsparcie inwestycyjne dla państw tego regionu. ${ }^{20}$

JAES określa długofalowe cele dla rozwoju stosunków między kontynentami afrykańskim i europejskim, które będą służyć realizacji wspólnie zaakceptowanych

17 Nie należy wykluczać, że to rozwiązanie nabierze znaczenia podczas negocjowania warunków liberalizacji handlu z UE czy w przyszłości z WTO.

18 EU Strategy for Europe: Towards a Euro-African Pact to Accelerate Africa’s Development, COM (2005)48S.

19 Constituve Act of the African Union, 11.06.2000, http://www.au.int/en/sites/default/files/ ConstitutiveAct_EN.pdf (13.10.2012).

20 The Africa-EU Strategy Partnership. A joint Africa-EU Strategy (JAES), s. 22. 
działań i interesów. Koncepcja ta opiera się na wspólnej wizji i wspólnie zatwierdzonych zasadach. JAES można uznać za ramy polityczne określające zakres wzajemnych stosunków między Afryką a UE. W dokumencie tym można znaleźć cztery główne cele obejmujące:

- poprawę partnerstwa afrykańsko-europejskiego;

- promocję: (1) pokoju, bezpieczeństwa, zarządzania demokratycznego i przestrzegania praw człowieka i (2) podstawowych wolności i równości płci; (3) zrównoważony rozwój gospodarczy, włączając $w$ to proces uprzemysłowienia; (3) regionalną i kontynentalną integrację; (4) gwarancje, że cele milenijne ONZ zostaną osiągnięte w pełni we wszystkich państwach afrykańskich do 2015 roku;

- efektywny multilateralizm;

- partnerstwo oparte na ludziach i kontaktach między nimi.

Przyjęte we wspólnej strategii cele są urzeczywistniane w ramach planów działania, które służą już obecnie do wzmocnienia dialogu politycznego między kontynentami afrykańskim i europejskim. Trzonem kolejnych planów działania było osiem problemów tematycznych:

- pokój i bezpieczeństwo,

- demokratyczne zarządzanie i prawa człowieka,

- regionalna integracja gospodarcza, handel i infrastruktura,

- milenijne cele rozwoju,

- zmiany klimatyczne,

- energia,

- migracja, mobilność i zatrudnienie,

- nauka, społeczeństwo informacyjne, przestrzeń kosmiczna.

Kolejnym krokiem po przyjęciu strategii, której celem jest rozwój Afryki (2005), była strategia o partnerstwie, przyjęta w Lizbonie w 2007 roku. Na podstawie tego ramowego dokumentu wzmocniono dialog polityczny i poszerzono współpracę. Utworzono przedstawicielstwo UE przy Unii Afrykańskiej w Addis Abebie. W procesie dialogu politycznego zaangażowany jest Parlament Europejski, który regularnie organizuje spotkania z Parlamentem Panafrykańskim.

Ważną rolę w procesie przemian państw afrykańskich odgrywa Europejski Bank Centralny, który regularnie organizuje spotkania z państwami Afrykańskiej Unii Walutowej oraz bankami centralnymi państw afrykańskich.

W ramach dialogu politycznego realizowany jest program nazwany Afrykańskim Instrumentem Pokojowym.

Dialog polityczny między UE a państwami Afryki prowadzony jest na pięciu płaszczyznach; są nimi: 
- organizowane co trzy lata szczyty; pierwszy odbył się w Kairze w dniach 3-4 kwietnia 2000 roku, drugi - 9 grudnia 2007 roku w Lizbonie, trzeci, ostatni - 29-30 listopada 2010 roku w Libii; następny szczyt odbędzie siew 2013 roku;

- spotkania ministerialne;

- wspólne grupy zadaniowe, powoływane do rozwiązywania aktualnych problemów, które pojawiają się we wzajemnych relacjach;

- poziom ekspercki;

- spotkania międzyparlamentarne.

Komisja Europejska ściśle współpracuje z instytucjami Unii Afrykańskiej i organizacjami pozarządowymi (NGO) z Afryki i państw europejskich.

Ostatni szczyt w Libii w 2010 roku zrewidował układ z Cotonou z 2000 roku, który zawierał cele na lata 2000-2020. Umowa dotyczyła ramowych warunków dla wzajemnych stosunków UE-ACP.

Unia Europejska z państwami Afryki realizuje kolejny, drugi plan działania. Obejmuje on lata 2011-2013. Wcześniejszy, pierwszy plan działania obejmował lata 2008-2010. Obecnie realizowany plan działania utworzono po analizie doświadczeń z pierwszego, starając się wyeliminować słabości poprzedniego planu, a także zbyt optymistyczne i dalekosiężne zamierzenia. Stan urzeczywistnienia celów zawartych w planach działania ma miejsce na szczytach UE-UA. Do osiągnięć realizacji planu działania - zgodnie z ostatnim przeglądem dokonanym na szczycie UE-UA - zaliczono:

- wsparcie w kwocie 1 mld euro działań pokojowych i bezpieczeństwa na kontynencie afrykańskim;

- przekazanie żywności i produktów rolnych o wartości 1 mld euro w ramach instrumentu finansującego bezpieczeństwo wyżywienia na kontynencie;

- szkolenia dla obserwatorów podczas wyborów przeprowadzanych w państwach afrykańskich;

- $168 \mathrm{mln}$ w grantach, które umożliwiły sfinansowanie budowy infrastruktury w Afryce, projektu wartego 2 mld euro;

- stworzenie Sieci Diaspory Afrykańskiej, co sprzyja kontaktom i zaangażowaniu emigrantów w problemy rozwoju kontynentu ich korzeni;

- zapewnienie dostępu do energii dla 2,5 mln osób zamieszkujących najbiedniejszy kontynent na świecie;

- przygotowanie wspólnej deklaracji na temat zmian klimatu;

- udostępnienie środków stypendialnych na finansowanie nauki za granicą i badania w kraju oraz umożliwiających uczestnictwo w badaniach prowadzonych przez międzynarodowe zespoły badawcze. 
To kilka najważniejszych działań wskazujących na potencjał, jaki może wyzwolić współpraca UE-UA. Dotychczasowa współpraca oraz analiza jej zakresu wskazuje na potrzebę zacieśnienia kontaktów z UE i instytucjami finansowymi (EBI, WB, AfDB i BADEA). Zaproponowano również powołanie do życia wspólnie wspieranego Finansowego Instrumentu Integracji Afrykańskiej (African Integration Facility). Taki instrument $\mathrm{i}$ jego wsparcie uznaje się za korzystne dla dalszego osiągania celów milenijnych ONZ oraz działań zaplanowanych w ramach obecnego planu działania, a także następnych planów tego rodzaju. ${ }^{21}$ Podkreślono, że przyjmowane strategie i plany działania będą traktowane jako ramy orientacyjne dla wspólnego lokowania środków finansowych, które są dostępne $\mathrm{w}$ ramach unijnych polityk oraz instrumentów finansowych, czego przykładem są: EDF, ENPI, DCI, IfS, EIDHR, EIB. ${ }^{22}$

\section{Rysunek 1. Dynamika PKB w cenach bieżących w UE-27 i państwach Afryki w latach 2000-2009 $(2000=100 \%)$}

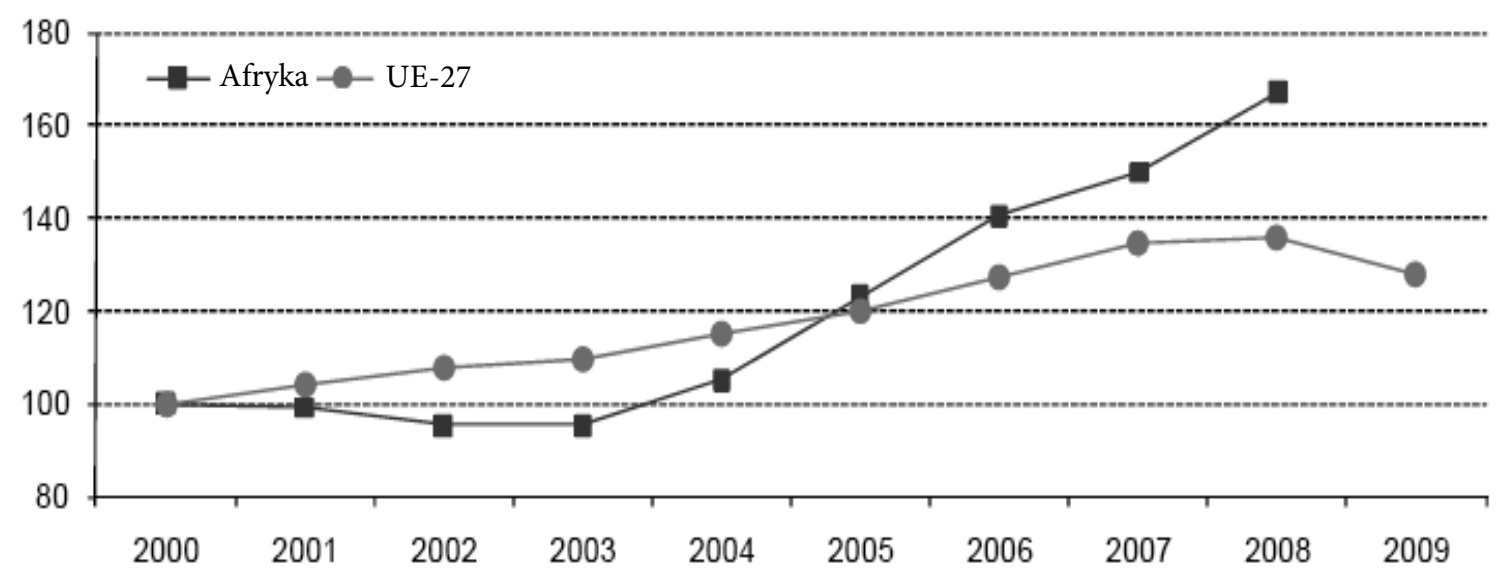

Źrodło: Eurostat, Komisja Europejska (16.10.2012).

Dynamika wzrostu PKB państw afrykańskich była wyższa od dynamiki obserwowanej w UE-27 od 2005 roku. Częściowo efekt ten może być wyjaśniony wzrostem cen w państwach afrykańskich. Pewien wpływ na dynamikę wzrostu PKB w państwach afrykańskich miał wzrost eksportu z UE-27. Ten rosnący trend w handlu załamał się w 2009 roku. Kryzys 2008-2009+ spowodował spadek importu UE-27 z Afryki o 33\%, eksport UE-27 na rynki afrykańskie spadł o blisko $10 \%$. W 2009 roku największym eksporterem z Afryki na rynek UE-27 była Libia, po stronie importu największym partnerem UE-27 na kontynencie afrykańskim była RPA.

W latach 2000-2008 dynamika wzrostu PKB w Afryce (rozpatrywanej jako całość) była wyższa niż dynamika wzrostu PKB UE-27. Doprowadziło to do

21 Joint Africa EU Strategy. Action Plan 2011-2013, s. 11, http://www.consilium.europa.eu/uedocs/ cms_data/docs/pressdata/en/er/118211.pdf (14.10.2012).

22 Ibidem, s. 12. 
zwiększenia PKB w tym okresie w UE-27 o 36 p.p. w tym okresie, podczas gdy w Afryce przyrost PKB szacowany był na 67 p.p. Kryzys finansowy 2007-2008+ spowodował spadek PKB o 8 p.p. Dla państw afrykańskich brak na razie danych, które mogłyby służyć do kompleksowych porównań. ${ }^{23}$ Stosowanie zagregowanych danych jest rozwiązaniem, które ukrywa duże dysproporcje rozwojowe i przyrostu zanotowane między poszczególnymi rynkami. Nie ulega wątpliwości, że na uzyskane wyniki duży wpływ miały wiodące rynki tego kontynentu, do których należą: RPA, Nigeria, Egipt, Algieria, Maroko i Libia. Obserwowany w przedstawionych statystykach trend został zahamowany przez proces „wiosny w krajach Afryki Północnej”, która rozpoczęła się w 2011 roku, a następnie przez konflikt wywołany przez Libię w 2012 roku.

\section{Rysunek 2. Poziom PKB per capita w państwach Afryki i UE-27 w cenach bieżących w latach 2007, 2008 i 2009}

Afryka

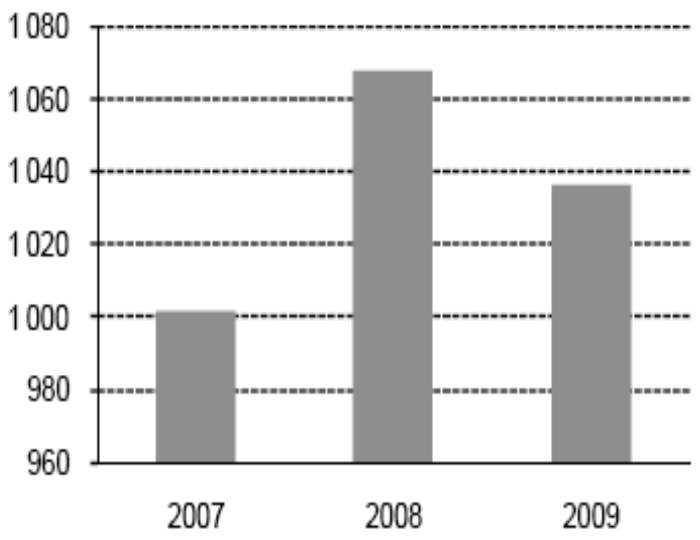

UE-27

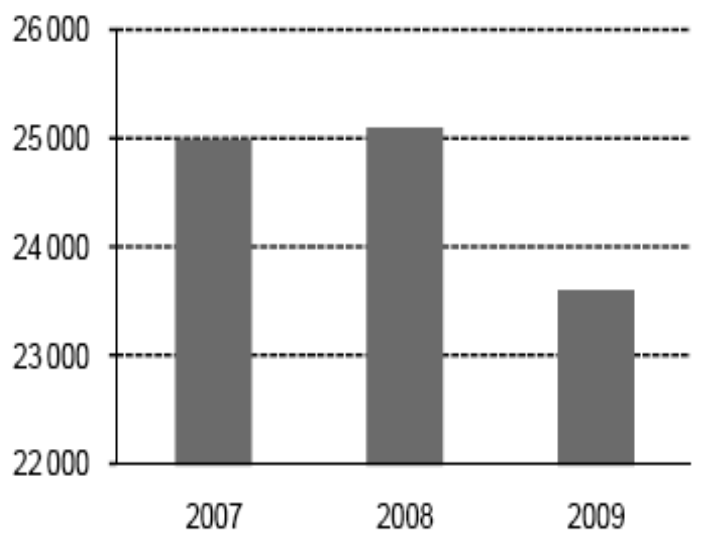

Źrodło: Eurostat, Komisja Europejska.

Rysunek 2 wskazuje na dysproporcje w dochodach per capita między państwami UE-27 a kontynentem afrykański. Ponownie należy zwrócić uwagę na wynik stosowanych skumulowanych statystyk dla rynków europejskiego i afrykańskiego. Niemniej jednak można dostrzec bardzo powolny proces pokonywania luki rozwojowej. Można założyć, że aktywizacja pełna potencjału, jaki istnieje w tym zakresie, może przenieść się na pozostałe gospodarki w regionie i przynieść skokowy efekt rozwojowy. Ma to szczególne znaczenie w kontekście poszerzenia grona państw, które mogą być zaangażowane w inwestycje, rozwój infrastruktury i tworzenie miejsc pracy na kontynencie afrykańskim. Obejmuje to nie tylko państwa OECD, ale i państwa BRIC czy G-20. ${ }^{24}$

23 Informacje oparte na wspólnym raporcie KE i UA sporządzonym w 2011 roku.

24 Afryka o godność życia, red. K.A. Kłosiński, Wydawnictwo KUL, Lublin 2012, s. 341-362, 131-148. 
Struktura gospodarki afrykańskiej, w której rolnictwo stanowi 16\%, może dawać zbyt optymistyczny obraz rzeczywistości. W państwach takich jak Czad, Liberia czy Sierra Leone udział sektora rolniczego w gospodarce przekracza 50\%. Podane informacje obejmujące charakterystyki dla całej Afryki dają zniekształcony obraz. Niemniej jednak wskazują na zmiany zachodzące na kontynencie, co obok zaangażowania się państw spoza kontynentu również można uznać za źródło impulsów prowzrostowych. Dotyczy to RPA, państw Afryki Północnej czy państw bogato zaopatrzonych w źródła energii. Zresztą nie tylko źródła energii i towarzyszące ich wydobyciu inwestycje stanowią czynnik nakręcający koniunkturę i sprzyjający zmianom rozwojowym w gospodarkach tego kontynentu. Podobną rolę pełnią inwestycje towarzyszące wydobyciu każdego surowca. ${ }^{25}$

\section{Rysunek 3. Struktura gospodarki w Afryce i UE-27 w 2007 roku}

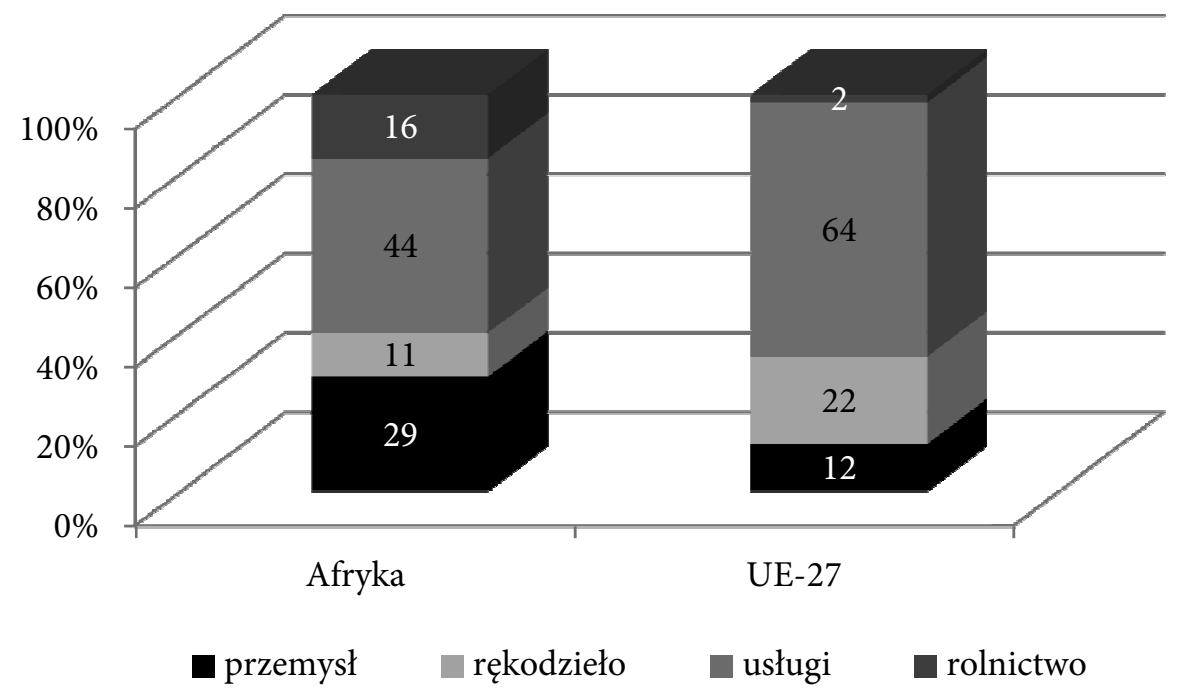

Źródło: Eurostat, Komisja Europejska.

Poprawa terms of trade może również tu być uznana za jeden z czynników zwiększających możliwości pokonywania luki rozwojowej w krajach surowcowych, czy specjalizujących się w produkcji rolnej. Nie jest to jednak nośne i efektywne źródło pokonywania luki rozwojowej. Większe możliwości daje przemysł oraz rozwój usług. Jak można zorientować się z rysunku 3, państwa afrykańskie, przynajmniej ich część, rozwijają usługi, które zaczynają dominować w strukturze gospodarki kontynentu.

25 World Investment Report 2007, Transnational Corporations, Extractive Industries and Development, UNCTAD, New York-Geneva 2007, s. 129-157. 
Nie jest to jednak równomierny proces, który obejmuje w takim samym zakresie wszystkie gospodarki kontynentu. Niemniej postęp jest widoczny.

Rysunek 4. Dynamika cen dóbr konsumpcyjnych w Afryce i UE-27 w latach 2000-2009

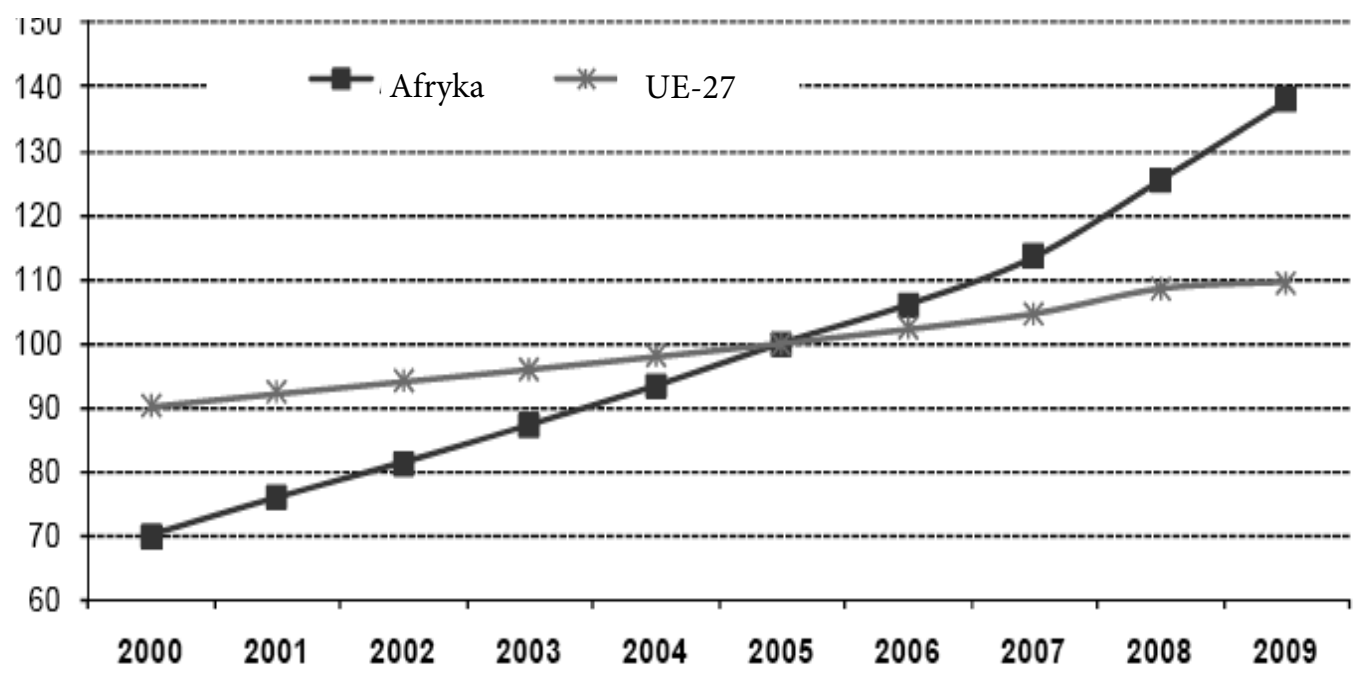

Źródło: Eurostat, Komisja Europejska.

Częściowo efekt wzrostu PKB jest wynikiem zmian cen oraz kursów głównych walut. Nie ulega jednak wątpliwości, że proces otwarcia gospodarek, stopniowa współpraca w regionie i subregionalna, której efektem jest wymiana handlowa oraz BIZ, przynosi również pewne efekty. Nie są one rozłożone równomiernie zarówno w grupie UE-27, jak i w grupie państw afrykańskich, niemniej można mówić o dobrym przykładzie, który może się rozprzestrzeniać w przyszłości, obejmując swym pozytywnym wpływem następne gospodarki i kraje.

\section{Rysunek 5. Handel UE-27 z Afryką w latach 2001-2009}

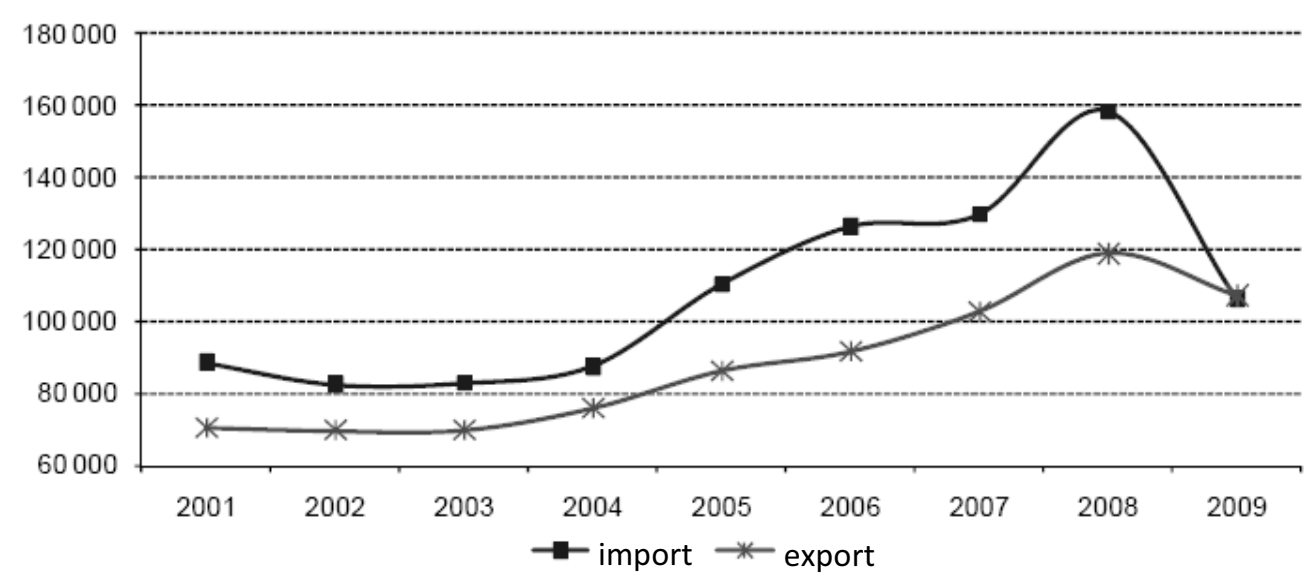

Źródło: Eurostat, Komisja Europejska. 
Zestawienie wskazuje, że polityka członkostwa państw afrykańskich w GATT/ $\mathrm{WTO}^{26}$ oraz przyjęte tu zasady określające uprzywilejowane warunki dostępu do rynku państw wysoko rozwiniętych spowodowały, że po długim okresie stagnacji wymiana handlowa między rynkiem afrykańskim i UE zaczęła rosnąć od 2000 roku. Widoczny jest również powiększający się deficyt we wzajemnych obrotach obu tych rynków, traktowanych jako całość. Niemniej jednak kryzys finansowy 2007-2008 załamał ten korzystny trend.

\section{Rysunek 6. Handel UE-27 z Afryką według struktury towarowej (SITC-1) w 2009 roku (w \%)}

\section{Zewnętrzny import UE-27 z Afryki}

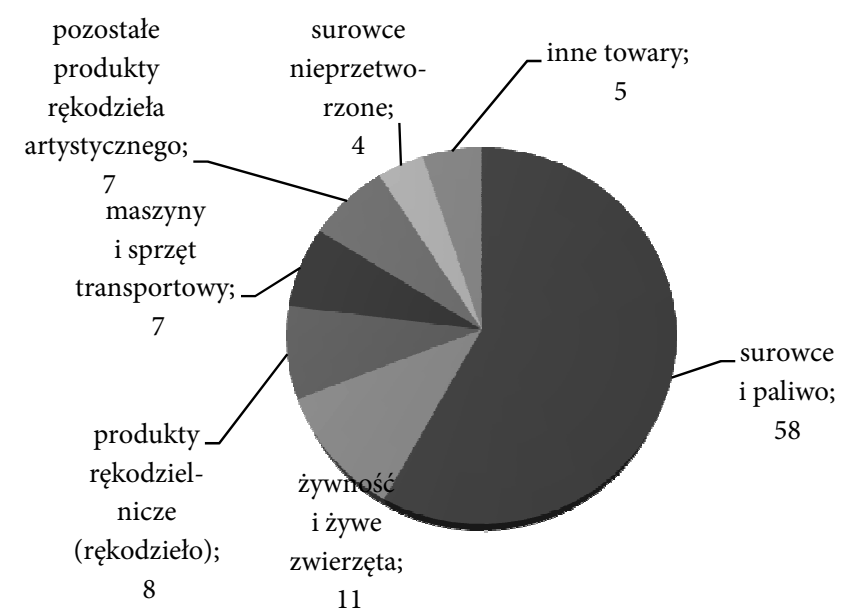

\section{Zewnętrzny eksport UE-27 do Afryki}

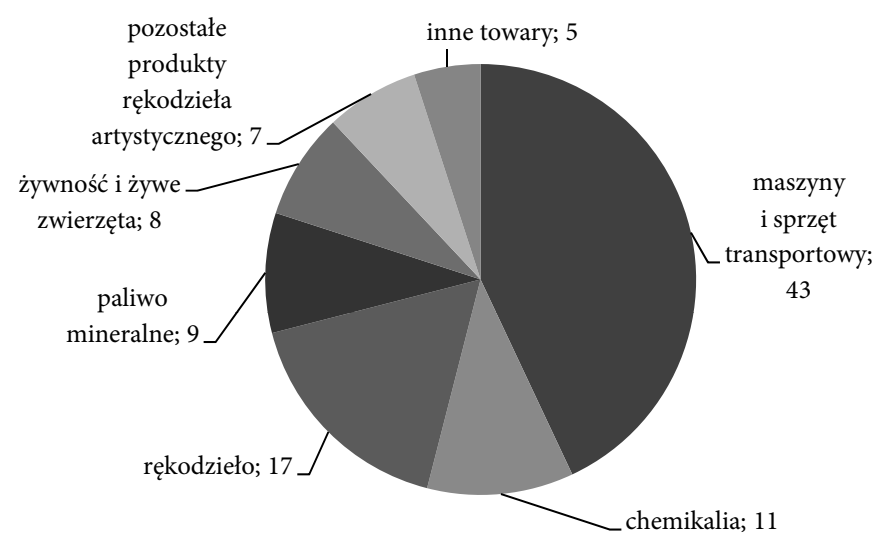

Źródło: Eurostat, Komisja Europejska.

${ }^{26}$ M. Grącik-Zajaczkowski, Państwa afrykańskie w WTO, w: Afryka o godność życia, op.cit. s. 241-260. 
Analiza struktury towarowej importu UE-27 z kontynentu afrykańskiego wskazuje na dominujący udział surowców energetycznych (56\%). Wzrost cen tych surowców może więc decydować o dynamice wzrostu wartości obrotów, a nie - jak można sądzić - wzrost ilościowy importowanych towarów. Niemniej jednak i tu we wzajemnych obrotach widoczne stają się zmiany strukturalne. Do zmian struktury eksportu z kontynentu afrykańskiego do UE-27 przyczynia się m.in. eksport UE-27, który jest zdominowany przez eksport maszyn i środków transportu.

Tabela 8 przedstawia głównych partnerów UE-27 po stronie importu i eksportu. $\mathrm{Na}$ obu listach powtarzają się te same rynki, choć obie listy różnią się również od siebie. Po stronie importerów z UE pojawiają się np. Kamerun czy Wybrzeże Kości Słoniowej - kraje te nie są eksporterami na rynek UE-27. Po stronie eksporterów pojawiają się takie kraje, jak Senegal czy Ghana, oba nie są państwami na liście dziesięciu partnerów importujących z UE.

Tabela 8. Wymiana handlowa UE-27 z Afryką w 2009 roku. Główne rynki, pozycja i wartość eksportu (w mln euro)

\begin{tabular}{|c|l|c|c|l|c|}
\hline \multicolumn{3}{|c|}{ Eksport UE-27 } & \multicolumn{3}{c|}{ Eksport z Afryki, najwięksi eksporterzy } \\
\hline poz. & \multicolumn{1}{|c|}{ rynek } & wartość eksportu & poz. & \multicolumn{1}{|c|}{ rynek } & wartość eksportu \\
\hline 1 & Libia & 19996 & 1 & RPA & 16040 \\
\hline 2 & Algieria & 17356 & 2 & Algieria & 14655 \\
\hline 3 & RPA & 14928 & 3 & Egipt & 12627 \\
\hline 4 & Nigeria & 10453 & 4 & Maroko & 11909 \\
\hline 5 & Tunis & 7891 & 5 & Nigeria & 9162 \\
\hline 6 & Maroko & 6510 & 6 & Tunis & 8931 \\
\hline 7 & Egipt & 6112 & 7 & Libia & 6471 \\
\hline 8 & Angola & 4916 & 8 & Angola & 5187 \\
\hline 9 & Wybrzeże Kości Stoniowej & 3055 & 9 & Ghana & 1749 \\
\hline 10 & Kamerun & 1744 & 10 & Senegal & 1628 \\
\hline
\end{tabular}

Źródło: Eurostat, Komisja Europejska, Main Indicators EU-27 trade with Africa, EU_ten_main_African_ partners_in foods_2009.PNG

Wymiana handlowa pociąga za sobą transfer BIZ. Tabela 9 przedstawia główne rynki odbierające inwestycje z UE-27, wartość skumulowanych inwestycji, kraje zaangażowane w eksport kapitału z UE oraz najważniejsze rynki eksportujące kapitał i importerzy kapitału z kontynentu afrykańskiego. Transfery bieżące BIZ oraz wartości skumulowane inwestycji zagranicznych w relacjach UE-27-Afryka charakteryzują się dużą dysproporcją. Dotyczy to zarówno udziałów rynku afrykańskiego w eksporcie kapitału z UE-27, jak i udziału inwestycji z tego kontynentu w skumulowanych wartościach inwestycji UE-27. 
Tabela 9. UE-27 skumulowane wartości BIZ do/z Afryki w 2008 roku

\begin{tabular}{|c|c|c|c|c|c|c|c|}
\hline \multicolumn{4}{|c|}{ Skumulowana wartość eksportu kapitału z UE-27 } & \multicolumn{4}{|c|}{ Skumulowana wartość importu kapitału z Afryki } \\
\hline rynek & $\begin{array}{l}\text { w mln } \\
\text { euro }\end{array}$ & $\begin{array}{c}\text { jako \% ogólnej } \\
\text { wartości BIZ } \\
\text { w Afryce }\end{array}$ & $\begin{array}{c}\text { jako \% ogólnej } \\
\text { wartości BIZ } \\
\text { UE-27 }\end{array}$ & rynek & $\begin{array}{c}\text { w mln } \\
\text { euro }\end{array}$ & $\begin{array}{c}\text { jako \% ogólnej } \\
\text { wartości BIZ } \\
\text { z Afryki } \\
\end{array}$ & \begin{tabular}{|c|} 
jako $\%$ \\
napływu BIZ \\
do UE-27 \\
\end{tabular} \\
\hline $\begin{array}{l}\text { Afryka, } \\
\text { w tym: }\end{array}$ & 153142 & 100 & 4,7 & $\begin{array}{l}\text { Afryka, } \\
\text { w tym: }\end{array}$ & 24868 & 100 & 1,0 \\
\hline RPA & 46345 & 30 & 1,42 & RPA & 5911 & 24 & 0,24 \\
\hline Nigeria & 25595 & 17 & 0,79 & Nigeria & 4675 & 19 & 0,19 \\
\hline Egipt & 20933 & 14 & 0,64 & Egipt & 4003 & 16 & 0,17 \\
\hline Maroko & 14133 & 9 & 0,43 & Maroko & 731 & 3 & 0,03 \\
\hline \multicolumn{4}{|c|}{ Główne państwa UE zaangażowane w eksport BIZ } & \multicolumn{4}{|c|}{ Gtówne państwa UE zaangażowane w import BIZ } \\
\hline Francja & 39394 & 26 & $()$. & Francja & 6079 & 24 & $()$. \\
\hline Wielka Brytania & 19998 & 13 & $()$. & Wielka Brytania & 2202 & 9 & $()$. \\
\hline Hiszpania & 5851 & 4 & $()$. & Hiszpania & 1315 & 5 & $()$. \\
\hline Wtochy & 5039 & 3 & (.) & Włochy & 1022 & 4 & $()$. \\
\hline
\end{tabular}

Źródło: Eurostat, Komisja Europejska.

Możliwości poprawy tych proporcji można upatrywać jedynie w zwiększeniu PKB państw afrykańskich. Bez spełnienia tego warunku nie można myśleć o znacznym zwiększeniu wzajemnych transferów BIZ. Skokowy wzrost transferów BIZ ze strony UE-27 czy szerzej państw OECD może wpłynąć na destabilizację finansową państw afrykańskich. Miałoby to negatywny wpływ na inflację oraz na aprecjację kursów ich walut, wywierając równocześnie negatywny wpływ na ich gospodarki i pogarszając możliwości rozwojowe.

Największymi inwestorami z UE-27 na kontynencie afrykańskim są byłe państwa kolonialne: Francja, Wielka Brytania, Hiszpania i Włochy. Te same gospodarki są odbiorcami inwestycji z państw afrykańskich. Europejskie inwestycje w Afryce nie przekraczają $5 \%$ ogółu inwestycji UE-27 transferowanych poza jednolity rynek. Inwestycje afrykańskie na rynku UE-27 nie przekraczają 1\% wartości inwestycji całkowitych, ponoszonych na tym rynku. Głównymi odbiorcami inwestycji europejskich są RPA, Nigeria, Egipt, Maroko. Te same państwa kierują swoje inwestycje na rynek europejski.

Porównując ostatnie dostępne szczegółowe dane dotyczące wzajemnych inwestycji między państwami afrykańskimi i UE-27, możemy zauważyć pojawienie się Niemiec jako inwestora w Afryce obok Francji, Hiszpanii i Wielkiej Brytanii. Natomiast po stronie importu kapitału z Afryki pojawił się Luksemburg, co wskazuje, że inwestorzy z Afryki poszukują możliwości lokowania swych inwestycji na rynku europejskim przy niskich podatkach. Obok tego „raju podatkowego” inwestycje z Afryki lokowano we Francji, Wielkiej Brytanii i Hiszpanii. 
Tabela 10. UE-27 transfery kapitału z/do Afryki w 2008 roku

\begin{tabular}{|c|c|c|c|c|c|c|c|}
\hline \multicolumn{4}{|c|}{ Eksport kapitału z UE-27 do } & \multicolumn{4}{|c|}{ Import kapitału do UE-27 z } \\
\hline rynek & $\begin{array}{l}\text { w mln } \\
\text { euro }\end{array}$ & $\begin{array}{l}\text { jako \% ogólnej } \\
\text { wartości BIZ } \\
\text { w Afryce }\end{array}$ & $\begin{array}{c}\text { jako \% ogólnej } \\
\text { wartości } \\
\text { eksportu kapitału }\end{array}$ & rynek & $\begin{array}{c}\text { w mln } \\
\text { euro }\end{array}$ & $\begin{array}{c}\text { jako \% } \\
\text { BIZ } \\
\text { z Afryki }\end{array}$ & $\begin{array}{c}\text { jako \% BIZ } \\
\text { z } \\
\text { zagranicy }\end{array}$ \\
\hline $\begin{array}{l}\text { Afryka, } \\
\text { w tym: }\end{array}$ & 18548 & 100 & 5,30 & $\begin{array}{l}\text { Afryka, } \\
\text { w tym: }\end{array}$ & 6040 & 100 & 3,000 \\
\hline Egipt & 9808 & 53 & 2,82 & Egipt & 3445 & 57 & 1,730 \\
\hline RPA & 2721 & 15 & 0,78 & RPA & 467 & 8 & 0,240 \\
\hline Nigeria & 1641 & 9 & 0,47 & Nigeria & 92 & 2 & 0,050 \\
\hline Maroko & 1517 & 8 & 0,44 & Maroko & 7 & 0,1 & 0,004 \\
\hline \multicolumn{4}{|c|}{$\begin{array}{c}\text { Gtówne państwa UE-27 zaangażowane } \\
\text { w eksport BIZ do Afryki }\end{array}$} & \multicolumn{4}{|c|}{$\begin{array}{c}\text { Gtówne państwa UE-27 zaangażowane } \\
\text { w import BIZ z Afryki }\end{array}$} \\
\hline Francja & 11341 & 61 & $()$. & Francja & 3092 & 51 & (.) \\
\hline Hiszpania & 1135 & 6 & (.) & Wielka Brytania & 1350 & 22 & (.) \\
\hline Wielka Brytania & 992 & 5 & $()$. & Luksemburg & 616 & 10 & (.) \\
\hline Niemcy & 911 & 5 & (.) & Hiszpania & 450 & 7 & (.) \\
\hline
\end{tabular}

Źródło: Eurostat, Komisja Europejska.

Oprócz zaangażowania się UE w rozwój kontynentu na zasadach bilateralnych UE-27-UA, UE-27 w ramach uzgodnień przyjętych podczas rundy urugwajskiej GATT zdecydowano, że wszystkie zasady liberalizacyjne powinny w takim samym stopniu dotyczyć wszystkich państw. Niemniej jednak wobec państw reprezentujących niższy poziom rozwoju zastosowano szereg wyjątków, które również znajdują zastosowanie w polityce handlowej UE wobec tej grupy państw. ${ }^{27}$ System ten nazwany jest systemem specjalnego i zróżnicowanego traktowania (Special and Different Treatment - SDT). Podstawą wymiany handlowej z państwami LDC (Less Developed Countries - gospodarki reprezentujące niski poziom rozwoju) jest Ogólny System Preferencji (General System of Preference - GSP) umożliwiający dostęp gospodarkom państw z listy LDC do rynków gospodarek reprezentujących wyższy poziom rozwoju. Wprowadza on asymetrię w procesie liberalizacji i stymuluje rozwój inwestycji w krajach reprezentujących niższy poziom rozwoju. Takie rozwiązania mogą mieć wpływ na rozwój tych gospodarek, co jest jednak warunkowane przygotowaniem odpowiedniej infrastruktury instytucjonalno-prawnej oraz rzeczowej (telekomunikacyjno-transportowej).

27 B. Hoeckman, M.M. Kostecki, Ekonomia światowego system handlu. WTO: zasady i mechanizmy negocjacji, Wydawnictwo UE we Wrocławiu, Wrocław 2011, s. 568. 
Państwa afrykańskie uczestniczą w kontaktach z UE w oparciu o różne umowy, które określają warunki dostępu do rynku oraz warunki dostępu do źródeł finansowych udostępnionych przez UE. Są to:

- śródziemnomorski kierunek polityki sąsiedztwa, a w ramach niego Euro-Meddierranean Asociation Agreement (EMAA), co miało prowadzić do utworzenia Euro-Med Free Trade Agreement;

- porozumienie z państwami AKP;

- porozumienie z Cotonou, ${ }^{28}$

- indywidualne działania państw prowadzące do reformowania stosowanych systemów celnych, obniżenia ceł, skrócenia czasu naliczania ceł i przeprowadzania transakcji (doświadczenia państw AKP:29 Haiti, Kamerunu, Etiopii czy Fidżi). ${ }^{30}$

Działania instytucjonalne wsparte są dodatkowo instrumentami finansowymi. Wszystkie instrumenty dostępne są w ramach Europejskiego Funduszu Rozwoju (EDF) i obejmują: ${ }^{31}$

- CIF (Caribbean Investemnt Facility) oraz IFP (Investment Facility for Pacific) oba ukierunkowane na inwestycje w infrastrukturę, na co przeznaczono łącznie $40 \mathrm{mln}$ euro;

- LAIF (Latin America Investment Facility);

- IFCA (Investment Facility for Central Asia);

- NIF (Neighborhood Investment Facility);

- ITF (EU-Africa Infrastructure Trust Fund).

Nowe mechanizmy pozwolą zaangażować się regionom zarówno w planowanie pewnych działań, jak i podejmowanie działań, gwarantując własność lokalną, co będzie miało zasadnicze znaczenie dla rozwoju przyszłej współpracy z UE.

W pewnym zakresie wpływ na obserwowane zjawiska ma proces dezindustrializacji zachodzący w krajach wysoko rozwiniętych, gdzie politycy często próbowali utrzymać dotychczasową strukturę gospodarki oraz wcześniejszą strukturę i poziom zatrudnienia.

W dokumencie podkreśla się wspólnotę interesów, której ważnym elementem staje się uprzemysłowienie państw afrykańskich, czemu towarzyszy dezindustrializacja państw europejskich. Działania te niosą określone koszty społeczne, czego dowodem jest rosnące bezrobocie w Europie, choć nie wszystkie gospodarki w podobnym

28 Rewizja w 2005 roku w Luksemburgu i następnie w 2010 roku w Quadanandougou.

29 Doprowadziły do wzrostu obrotów, wzrostu dochodów z wymiany handlowej, przysporzyły nowych rynków zbytu, obniżyły koszty naliczania ceł itp.

30 K. De Gucht, komisarz ds. handlu, EU-ACP: Completing Partnership EU-ACP. Parliamentary Assembly, Horens, Denmark, May 29, 2012.

31 EU Creates new Caribbean and Pacific Investment Facilities to Support Key Investments in Infrastructure, April 30, 2012. 
stopniu odczuwają ten problem. Przykładowo w Austrii (4,5\%) stopa bezrobocia kształtuje się na niższym poziomie od średniej dla UE (11,4\%), podobnie w Holandii (6,6\%), Wielkiej Brytanii (7,9\%), Niemczech (6,8), Danii (6,2\%) czy Szwecji (7,4\%). Wysoki poziom stopy bezrobocia odnotowany w UE jest wypadkową tendencji w tym zakresie we wszystkich krajach. Poziom stopy bezrobocia sięgający około $12 \%$ jest najwyższy w UE od czasu rozpoczęcia integracji. Decyduje o tym kilka czynników. Po pierwsze, wysoki poziom stopy bezrobocia w Grecji $(25,1 \%)$, Hiszpanii $(25,1 \%)$, Francji $(10,6 \%)$ czy we Włoszech (10,7\%). Po drugie, przyspieszenie procesu dezindustrializacji w gospodarkach, które hamowały przemiany strukturalne i miejsca pracy $\mathrm{w}$ przemyśle. Po trzecie, $\mathrm{w}$ niektórych państwach wysoki udział w zatrudnieniu nisko wydajnego sektora publicznego, co rzutuje na niską efektywność całej gospodarki. Każdy z wymienionych krajów należy traktować indywidualnie. Podobny poziom stopy bezrobocia w Hiszpanii i Grecji, mimo że kraje te zaliczane są do grupy tzw. biednego Południa UE, nie oznacza, iż przyczyny bezrobocia w obu przypadkach są podobne. Grecja opiera swoją gospodarkę na usługach, głównie turystyce. Niepokoje w Grecji zmniejszyły zainteresowanie turystów tym krajem. O spadku dochodów z turystyki, co miało wpływ na inne usługi konsumowane przez przyjeżdżających turystów, decydowały nie tylko niepokoje, ale również wzrost cen świadczonych usług po wprowadzeniu euro, czemu nie towarzyszył wzrost jakości świadczonych usług. Niski poziom usług mógł być tolerowanych przez pewną grupę turystów w warunkach niskich cen. Nie może jednak być tolerowany w warunkach wzrostu cen. Dodatkowym czynnikiem ograniczającym zainteresowanie wypoczynkiem w Grecji jest silna konkurencja ze strony Turcji. Oferta turystyczna jest tu nie tylko konkurencyjna cenowo, ale i jakościowo. W Grecji rozpoczął się również proces zwolnień z sektora publicznego, który miał duży udział w zatrudnieniu. Hiszpania natomiast jest gospodarką o relatywnie dużym udziale produkcji przemysłowej $\mathrm{w}$ zatrudnieniu, co w warunkach intensyfikującej się konkurencji ze strony towarów importowanych z rynków gospodarek wschodzących zaczyna stanowić pewien problem dla polityków tego państwa. Próby zatrzymania procesu przemian strukturalnych wiążą się z określonymi kosztami budżetowymi, a podnoszenie wydatków jest hamowane przez politykę ograniczającą wydatki i kierującą się celem, którym jest konsolidacja budżetowa. Analiza udziału wydatków socjalnych, które wzrosły w starych państwach UE w ostatnich latach, nie poprawia ani elastyczności rynku pracy, ani tym bardziej nie wpływa na podniesienie przedsiębiorczości w tych 
gospodarkach. Nie wpływa również na podniesienie wydajności i nie przekłada się na poprawę konkurencyjności oferowanej w tych krajach produktów. ${ }^{32}$

\section{UE-Azja (Indie, Chiny, Japonia, ASEAN)}

Unia Europejska i jej państwa członkowskie są zaangażowane w rozwój gospodarczy, procesy liberalizacji i reformy gospodarek wschodzących, w tym gospodarek wschodzących z obszaru Azji. Przykładem tego są kontakty z Indiami, Chinami, Japonią i państwami ASEAN.

Kontakty WE z Indiami - jeśli chodzi o ścisłą ich instytucjonalizację - sięgają 1994 roku, kiedy to został przygotowany Cooperation Agreement. W 2005 roku relacje między Indiami a WE weszły na wyższy poziom, co oznaczało przygotowanie Joint Action Plan. Został on zrewidowany w 2008 roku. Poszerzono wspólne działania o sferę bezpieczeństwa i stosunki międzynarodowe. Ważnym elementem współpracy stało się wspólne zwalczanie terroryzmu. W 2006 roku przyjęto dokument Country Strategy Paper for India 2007-2013 wyznaczający cele strategiczne dla polityki gospodarczej Indii, czemu towarzyszyło określenie finansowego instrumentu wsparcia ze strony UE. Było to $470 \mathrm{mln}$ euro na cały okres objęty planem strategicznym 2007-2013, co w skali rocznej dawało transfery w wysokości $67 \mathrm{mln}$ euro. W 2011 roku Strategy Paper został dodatkowo wzmocniony przez Multi-Annual Indicative Programmme 2011-2013. Dokument ten został podpisany w lutym 2011 roku. Praktyka wskazała, że reformy w Indiach oraz urzeczywistnianie celów zawartych we wcześniej przyjętych dokumentach wymagają wsparcia sektorów społecznych w Indiach, a w szczególności edukacji drugiego stopnia, kształcenia ustawicznego i zawodowego, finansowania projektów dotyczących rozwoju sektora energetycznego i technicznego wsparcia dla ochrony środowiska oraz rozwoju wymiany handlowej.

Kontakty między WE a Chinami zostały zapoczątkowane w 1975 roku. Dialog polityczny datuje się od 1994 roku. W 1998 roku przygotowany dokument zawierający zakres dialogu zaktualizowano i rozszerzono. W 2003 roku UE i ChRL zawiązały strategiczne partnerstwo. W 2010 roku zakres obszarów objętych strategicznym partnerstwem został rozszerzony m.in. o sferę bezpieczeństwa i stosunki zagraniczne. W 2012 roku w Pekinie odnowiono umowę strategicznego partnerstwa, dopasowując zakres podejmowanych działań do aktualnych potrzeb. ${ }^{33}$ Obejmuje to również

32 K. Żukrowska, The Eurozone Crisis and its consequences for the Polish Economy, 2012 (maszynopis przygotowany dla CES Yearbook, Budapest).

33 Joint Press Release at 3d EU-China High - Level Strategic Dialogue, A318/12. 
kwestie związane z problemami finansowymi UGiW i wpływu kryzysu strefy euro na gospodarkę światową. Ma to szczególne znaczenie dla wymiany handlowej z gospodarkami reprezentującymi niższy poziom rozwoju, dla których rynek UE (oraz USA) stanowiły ważny rynek eksportowy.

Traktat lizboński stał się podstawą do powołania stałego przedstawiciela ChRL przy Radzie Europejskiej. Kontakty między KE a ChRL są regularne. Co roku odbywają się szczyty na najwyższym szczeblu, regularnie spotykają się ministrowie resortowi. Regularnie też odbywają się spotkania grup roboczych gospodarczych i sektorowych. Dialogi sektorowe prowadzone są w 50 sektorach. Świadczy to o zaawansowaniu przygotowania bardziej szczegółowej umowy między tymi dwoma rynkami niż ta, która jest zawarta $\mathrm{w}$ strategicznym partnerstwie.

Dnia 20 września 2012 roku w Brukseli miał miejsce 15 szczyt UE-ChRL. ${ }^{34}$

Znaczenie kontaktów z ChRL dla UE jest duże z wielu względów. Do najważniejszych należy zaliczyć: (1) rosnąca rolę ChRL w wymianie handlowej i PNB świata; (2) rosnącą rolę ChRL w wymianie UE; (3) rolę ChRL w zmianach zachodzących w państwach Afryki czy Ameryki Łacińskiej; (4) udział rezerw ChRL w rezerwach walut w skali świata.

Relacje Unii Europejskiej z Japonią mogą wydawać się w kontekście niniejszego opracowania chybione. Tak jednak nie jest. Mimo że Japonia jest państwem członkowskim OECD, a więc gospodarką wysoko rozwiniętą, podobnie jak część państw UE ma problemy z szeregiem reform umożliwiających liberalizacje gospodarki i szersze otwarcie własnego rynku dla inwestycji zagranicznych. W 2001 roku Japonia i UE podpisały Action Plan. Nawiązany między UE i Japonią dialog polityczny ma pomóc Japonii we wprowadzeniu zmian prawno-regulacyjnych.

Relacje UE z ASEAN odbywają się na zasadach zinstytucjonalizowanych w ramach ASEM.

ASEM to regularne spotkania między UE a państwami członkowskimi ASEAN. ASEAN praktycznie obejmuje swym zasięgiem cały kontynent Azji, UE - cały kontynent Europy. Łącznie ich relacje obejmują oba kontynenty. PKB tych dwóch ugrupowań daje wartość połowy PKB świata, 60\% ludności i 60\% światowej wymiany handlowej. Dialog ASEM nie zastępuje jednak stosunków bilateralnych na poziomie państw.

Partnerami ASEM jest 27 państw członkowskich UE, 10 państw członkowskich ASEAN (Brunei, Kambodża, Indonezja, Laos, Malezja, Birma/Mianmar, Filipiny, Singapur, Tajlandia, Wietnam) oraz Australia, Chiny, Indie, Japonia, Korea Płd.,

34 15th EU-China Summit: Joining Forces in Challenging Times, Brussels, September 19, 2012, EUCO 170/12. 
Pakistan, Rosja, Mongolia, Nowa Zelandia, Pakistan, Rosja, Sekretariat ASEAN i Komisję Europejską. Trzy nowe państwa dołączą do ASEM podczas najbliższego listopadowego szczytu. Są to Szwajcaria, Norwegia i Bangladesz.

Zgodnie z planem kolejny szczyt ASEM odbędzie się w dniach 5-6 listopada 2012 roku w Wientianie (Laos), a jego motto brzmi dość wymownie: „Przyjaciele w pokoju, Partnerzy dla dobrobytu". W latach 2012-2015 UE alokowała na rzecz urzeczywistniania celów ASEM 3 mln euro. Jest to czwarta faza realizacji planu wspierana przez instrument finansowy UE. Środki te zasilają Fundację Azja-Europa (ASEF).

W 2011 roku wymiana handlowa $\mathrm{z}$ azjatyckimi członkami ASEM (Brunei, Kambodżą, Chinami, Indiami, Indonezją, Japonią, Koreą Płd., Laosem, Malezją, Mongolią Birmą/Mianmarem, Pakistanem, Filipinami, Singapurem, Tajlandią i Wietnamem) osiągnęła wartość $330 \mathrm{mln}$ euro w eksporcie i $532 \mathrm{mld}$ euro w imporcie. Wymiana handlowa z tymi państwami osiągnęła wartość jednej czwartej handlu UE z rynkami zewnętrznymi spoza rynku wewnętrznego.

Współpraca UE z państwami azjatyckimi przebiega zgodnie z podobnym schematem jak w innych regionach, przy czym dotyczy ona relatywnie wysoko rozwiniętego rynku, z którym UE ma bardzo rozwinięte kontakty handlowe. Jest to rynek, który z pewnością może przyjąć na siebie większą odpowiedzialność za kształtowanie przyszłych stosunków gospodarczych, prowadząc do rozwoju regiony charakteryzujące się relatywnie wysokim zacofaniem. UE oraz USA mają podpisane umowy o wolnym handlu z Koreą Płd., umowy stowarzyszeniowe negocjowane są z Indiami. Postęp w tym zakresie oraz zaawansowanie współpracy z państwami tego regionu wskazuje, że będzie się ona zacieśniać i należy się spodziewać, że w przyszłości wywrze większy wpływ na kształtowanie stosunków międzynarodowych i wspólne podnoszenie dobrobytu w regionach reprezentujących niższy poziom rozwoju.

\section{Zakończenie}

Unia Europejska pełni rolę „tutora” we wszystkich trzech analizowanych regionach państw WNP, w Afryce i Azji. Trzy wymienione grupy państw reprezentują nie tylko różny poziom rozwoju, ale - co jest z tym związane - także inny poziom włączenia się do "głównego nurtu” gospodarki światowej.UE stara się przez odpowiednio przygotowane umowy instytucjonalizujące wzajemne stosunki pomóc państwom 
z tych regionów w ich reformach. Dotyczy to zarówno Japonii - państwa wysoko rozwiniętego i członka OECD, jak i Kamerunu, państwa zaliczanego do grupy najmniej rozwiniętych. Problem ten rozwiązany jest według podobnego modelu: umów partnerskich i deklaracji określających przyjęte plany działania. Skuteczność UE (Komisji) w jej działaniach wynika $\mathrm{z}$ tego, że jest to rodzaj zewnętrznej kontroli, co bardzo często jest wspierane finansowo, a więc daje KE prawo do kontroli, wyrażania opinii, porad, krytyki i wskazywania niedociągnięć.

Znając polskie doświadczenie w sferze transformacji, w czym KE i UE odegrały ważną rolę, można uznać, że przyjęte rozwiązanie będzie skuteczne w przypadku państw WNP, Afryki i Azji. Powodzenie jest tym bardziej prawdopodobne, że UE ma opinię skutecznej instytucji w sferze przemian prowadzących państwa do sukcesu, jakim jest wzrost dobrobytu. W przypadku Japonii chodzi nie tyle o wzrost dobrobytu, ile o możliwość przeprowadzenia reform, które będą oznaczały liberalizację wewnętrzną tej gospodarki.

Komisja Europejska świadczy pomoc merytoryczną, ekspercką, finansową i kontroluje wywiązywanie się $\mathrm{z}$ deklaracji złożonych przez państwo. Pomaga również $\mathrm{w}$ otwieraniu gospodarek $\mathrm{w}$ regionie, przygotowującym państwa do współpracy regionalnej, subregionalnej i globalnej. Instytucjonalizacja stosunków bilateralnych i multilateralnych pomaga urzeczywistniać przyjęte cele. Obok współpracy gospodarczej dobrze rozwija się współpraca między instytucjami finansowymi. Liderami w tym zakresie są EBC i ESBC, które współpracują z lokalnymi, krajowymi bankami centralnymi regionów objętych procesem instytucjonalizacji.

\section{State of agreements between $\mathrm{EU}$ and international environment (CIS, Africa and Asia)}

The paper analyzes solutions used in the process of institutionalization of relations between UE, CIS member states and the states of Asia and Africa. It also analyzes influence of institutionalization of economic cooperation, particularly export and import, on the position of states involved. Different solutions, such as GSTP for least developed countries, are used. Attention is drawn to the asymmetry in trade relations with the less developed countries, which are given preferential access to EU markets. Those solutions are additionally strengthened by financial instruments. It seems that the results of these actions are positive: GNP increase of African states is higher than the GNP increase of EU-27, especially after 2009. The importance of European Commission and EBC is underlined as an important 
factor that stimulates growth in those countries. Similar cooperation but on different level is also observed in regard to other continents. The cooperation between Asia, Africa and CIS countries is not limited to transfer of funds. It also includes internationalization of contacts and liberalization of trade, services and capital flow as well as cooperation in research and support of economic transformation. The solutions applied are different for each country, however they are based on the same principles.

\section{Состояние договоров ЕС с международным окружением (казус СНГ, государств Африки и Азии)}

В тексте обсуждаются решения применены в процессах институционализации отношений между ЕС и государствами СНГ, Азиатского и Африканского континентов. Анализу также подлежит влияние институцио-нализации экономических связей на позицию отдельных государств, обнятых этим процессом во взаимном обмене с ЕС, что относится к импорту и экспорту. Представлены здесь приняты, достаточно разнообразные, решения. Указывается на применение GSTP (системы торговых пре-ференций) к государствам с наиболее низко развитой экономикой. Обзращается внимание на асимметрию примененных торговых решений в отношении к странам, которых экономика представляет более низкий уровень развития. Эта асимметрия означает более широкий доступ на рынок ЕС экспортеров из третьих стран чем в противоположном направлении. Такое решение является формой протекции менее развитых рынков и формой либерализации для экспортеров из этих рынков на рынок ЕС. Институциональные решения, которые стимулируют обмен, добавочно подкрепляются финансовыми инструментами доступными в рамках Европейского Фонда Развития. Все примененные решения приносят определенные результаты, чего доказательством могут быть, хотя бы, показатели более высокой динамики роста ВВП в государствах Африки по сравнению с динамикой наблюдаемой в ЕС-27. Это касается особенно периода после 2009 г. Подчеркиваеться значение Еврокомиссии в стимулировании развития в обсуждаемых регионах. Похожую функцию также приписывается связям ЕЦБ с центральными банками и министерствами финансов и экономики государств региона. Аналогичное сотрудничество, хотя и в разной степени и сфере, наблюдается и на других континентах. Каждый из обсуждаемых континентов - Африка и Азия - и страны СНГ тесно сотрудничат с ЕС. Это сотрудничество не ограничивается передачей помощи, чему 
сопутствует институционализация контактов и либерализация, дающая доступ к восприимчивому экспортному рынку, или приобретения передовых технологий. ЕС, кроме товарной торговли, обслуживания и трансфера капитала, организует сотрудничество в области исследований и развития, поддерживает экспертизами процессы перемен, приближает сотрудничающие с ним страны к включению их в основное русло мировой экономики. Несмотря на многие общие черты, которые можно заметить в примененных моделях сотрудничества, у них много и различий. Они возникают из попытки приспособить каждый раз модели сотрудничества к местным потребностям и уровню развития. Тем не менее, примененные решения построены на тех же самых устоях. 